\title{
Implementing the Anticancer Clauses of the Food, Drug and Cosmetic Act
}

\author{
On April 15, 1977, the Food and Drug Administration (FDA)
} proposed to ban the use of saccharin in prepackaged foods and as a tabletop sweetener. ${ }^{1}$ The FDA's proposed regulation cited a recent Canadian study which, in the FDA's opinion, "confirmed what earlier American studies have suggested: that saccharin poses a significant risk of cancer in humans." The FDA's withdrawal of saccharin's approval as a food additive is popularly viewed as predicated on the anticancer clause (also known as the Delaney Amendment) in the Food, Drug and Cosmetic Act. ${ }^{3}$

Public reaction to the proposed ban has been tumultuous. The flurry of Congressional activity following the FDA's announcement promises to revitalize the controversy over the social costs and benefits of the anticancer clauses. ${ }^{4}$ That reexamination is clearly in order, but it would be a mistake if its focus were skewed by preoccupation with the saccharin controversy. The federal government has

142 Fed. Reg. 19996 (1977). The Commissioner proposed to permit the submission of new drug applications for the marketing of saccharin as a single ingredient over-the-counter drug. Id. at 20004. That saccharin may be considered a human drug as well as a food additive was apparently recognized by the FDA as early as 1942 . Food Drug Cos. L. REP. (CCH) If 70,051.39 (1969) (FDA TC38, July 27, 1942). For example, saccharin is used by persons afflicted with diabetes, obesity, reactive hypoglycemia, and carbohydrate-induced hyperlipemia.

242 Fed. Reg. 19996 (1977). In the Canadian study twenty-one of 200 rats whose mothers were fed saccharin and that were subsequently weaned to the same diet developed bladder tumors, while only one control rat developed bladder tumors. Id. at 20000 . This study, however, did not convincingly show that rats exposed to saccharin only after birth display more bladder tumors than rats not so exposed. 296 NEw ENGLAND J. MED. 1348 (1977). Evidence of a positive correlation between saccharin intake and the incidence of bladder tumors in human males surfaced after the FDA's proposal to withdraw the substance. See Howe, Bunch, Miller, Morrison, Gordon, Weldon, Chambers, Fodor \& Winsor. Artificial Sweeteners and Human Bladder Cancer, 1977 LANCET 578. For criticism of this study see 1977 LANCET 592.

3 The anticancer clause applicable to food additives is found in $\S 409$ (c)(3)(A) of the Federal Food, Drug, and Cosmetic Act [hereinafter cited as FDCA], 21 U.S.C. \& 348(c)(3)(A) (1970). FDA's proposed withdrawal of saccharin is actually based not only on the anticancer clause, but also on the general safety clause of section 409.42 Fed. Reg. 20002 (1977).

- During the first session of the 95th Congress fifty-seven bills were introduced to modify the anticancer clause in some manner; sixty bills were introduced to deal specifically with saccharin. Telephone interview with Jan Hardy of the Office for Legislative Services, Food and Drug Administration. The bill that has received the most attention is H.R. 5166, introduced by Representative Martin, which would permit the agency to balance the benefits of certain food additives against their demonstrated health risks. Id. Deferring final resolution of the saccharin controversy, the Senate on September 15, 1977, passed S. 1750, which imposes an eighteen month moratorium on action to ban saccharin. Food CHEMICAL News, September 19,1977 at 46. 
been regulating toxic substances since $1906^{5}$ and an anticancer clause has been part of the statute since $1958 .{ }^{6}$ Discussion of the anticancer clauses cannot ignore the history of FDA regulation of carcinogenic substances.

The purpose of this comment is to examine the problems that have arisen in implementing the anticancer clauses. The FDA's record in regulating carcinogens has been marked by long delays, ${ }^{7}$ inconsistent results, ${ }^{8}$ and exposure to political pressure. ${ }^{9}$ These diffi-

5 The first major effort was the Food, Drug, and Cosmetic Act of 1906, 34 Stat. 786 (1906). For a history of food and drug legislation in the United States, see Turner, Principles of Food Additive Regulation, in 2 Consumer Health and Products Hazards 289 (S. Epstein \& R. Grundy eds. 1974).

- The Food Additives Amendment of 1958, Pub. L. No. 85-929, 72 Stat. 1784, added FDCA § 409, which contains an anticancer proviso. FDCA $\S 409$ (c)(3)(A), 21 U.S.C. $\S$ $348(\mathrm{c})(3)(\mathrm{A})(1970)$.

7 A 1962 study of Violet 1, a color additive, suggested that it might be carcinogenic. See Mannell, Grice \& Allmark, Chronic Toxicity Studies on Food Colours, 14 J. Pharmacy \& Pharmacology 378 (1962). The provisional certification of the color was not terminated until 1973. 38 Fed. Reg. 9077 (1973).

Evidence of the carcinogenicity of nitrofurans (an animal drug) first surfaced in 1966. See J.E. Morris, The Carcinogenic Activity in the Rat of Some Derivatives of 5-Nitrofuran (1966) (unpublished dissertation at the University of Wisconsin). While a proposed regulation has been issued that would withdraw nitrofurans from the market, 41 Fed. Reg. 19906 (1976), no action has yet been taken. See 21 C.F.R. $\S \S 510.515$ (a)(4-5), (b)(15), (b)(17)(ii), (c)(8-10), $556.290,558.15(\mathrm{~g})(1-2)$, and $558.262(1977)$.

Cyclamate-treated animals developed a high incidence of lymphosarcomas during a study conducted by FDA in 1950. These findings were not reported until 1969. Although there have been differences of opinion regarding the significance of these tumors, the possibility of carcinogenicity certainly should have been raised. See Regulatory Policies of the FDA, Hearing before a Subcomm. of the House Comm. on Government Operations, 91 Cong., 2d Sess. 108 (1970). Cyclamates were removed from the market on August 27, 1970. 35 Fed. Reg. 13644-45 ((1970)(revoking 21 C.F.R. $\$ \S 2.121(\mathrm{~m}), 3.75,130.40$, and 130.43 (1970)).

Evidence that saccharin might be carcinogenic was reported in 1951. See Fitzhugh Nelson \& Frawley, A Comparison of the Chronic Toxicity of Synthetic Sweetening Agents, $40 \mathrm{~J}$. Am. Pharmaceutical Ass'n 583 (1951).

8 The provisional listing of F.D. \& C. Red No. 2 was terminated because no study was "available to resolve the uncertainties concerning the safety of F.D. \& C. Red No. 2." 41 Fed. Reg. 5824 (1976). However, F.D. \& C. Red No. 40, the dye that is expected to replace Red No. 2, "has not been subjected to the kinds of tests some experts consider necessary to establish its safety." Color Additives: Is Successor to Red Dye No. 2 Any Safer?, 191 SciEncE 832 (1976). The Canadian government, evaluating essentially the same data as that available to the FDA, removed Red No. 40 from the market, but continued to permit the use of Red No. 2. See Canada Ministry of Health \& Welfare, Canadian Position on the Food Colour Amaranth (News Release, Feb. 2, 1976). Allied Chemical, holder of the patent on Red No. 40 , has submitted test results that showed that six of 400 test mice developed premature and unexpected malignant lymphomas after 41 weeks of a 76-week feeding study. FDA News Release, Food Drug Cos. L. REP. (CCH) I 41,588 (Feb. 28, 1976). An interagency working group evaluating F.D. \& C. Red No. 40 recently concluded that the FDA should delay decision until further tests are conducted. See Interim Report Working Group on F.D. \& C. Red No. 40 (January 19, 1977) (unpublished FDA report).

- See, e.g., Boffey, Death of a Dye, N.Y. Times, Feb. 29, 1976 (Magazine), at 9:

It had been a rough few months for Alexander M. Schmidt, Commissioner of Food and 
culties have been due in large part to underlying problems of statutory interpretation, to the failure of the FDA to issue regulations and establish standards, and to the inherent difficulty of drawing legal conclusions on the basis of inconclusive and often conflicting scientific evidence.

The comment will first delineate the statutory framework in which the anticancer clauses operate. Second, it will discuss the problem of defining and identifying carcinogens. The last section of the comment will examine the scope of the anticancer clauses.

\section{The Statutory Framework}

The Federal Food, Drug and Cosmetic Act ${ }^{10}$ establishes the procedures and criteria for the regulation of chemicals found in food. Section 301 prohibits the introduction or delivery for introduction into interstate commerce of any adulterated food, the adulteration of any food in interstate commerce, the receipt and delivery or proffered delivery of any adulterated food in interstate commerce, and the manufacture of any adulterated food." Section 402 of the Act defines adulteration. ${ }^{2}$ The statute, as enacted in 1938, classifies all

Drugs, as he worried over the controversial color additive Red No. 2. First, the General Accounting Office and Senator Gaylord Nelson charged that his agency had dillydallied for 15 years without making a final decision on the safety of Red No. 2 and thereby exposed the public to needless risk. Next, the Health Research Group, a Ralph Nader affliate that had led the charge against Red No. 2 for four years, complained that serious safety questions were still unresolved. Then came a grueling appearance on CBS-TV's Face the Nation where reporters badgered Schmidt to explain why he had not taken Red No. 2 off the market....

The political pressures are due in large part to the increasing incidence of certain types of human cancer. The trend has been widely noted. See, e.g., S. Doc. No. 9, 92d Cong., 1st Sess. 31 (1970). The recognition that many cancers are caused by exposure to chemicals in the environment has spawned additional concern. See Cairns, The Cancer Problem, 233 Scientific AM. 64 (1975); Epstein, Environmental Determinants of Human Cancer, 34 Cancer Research 2425 (1974); World Health Organization, Prevention of Cancer (Tech. Rep. Ser. No. 276, 1964).

10 21 U.S.C. $\$ \S 301-392$ (1970).

" 21 U.S.C. $\$ 331$ (1970).

1221 U.S.C. $\$ 342(1970)$. Section 402 provides, in relevant part:

A food shall be deemed to be adulterated-

(a)(1) If it bears or contains any poisonous or deleterious substance which may render it injurious to health; but in case the substance is not an added substance such food shall not be considered adulterated under this clause if the quantity of such substance in such food does not ordinarily render it injurious to health; or (2) (A) if it bears or contains any added poisonous or added deleterious substance (other than one which is (i) a pesticide chemical in or on a raw agricultural commodity; (ii) a food additive; (iii) a color additive; or (iv) a new animal drug) which is unsafe within the meaning of section 346 of this title, or (B) if it is a raw agricultural commodity and it bears or contains a pesticide chemical which is unsafe within the meaning of section $346 a(a)$ of this title, or (C) if it is, or if it bears or contains, any food additive which is unsafe within the meaning of section 348 of this title ... . 
"poisonous and deleterious substances" as either "added" or "not added."13 Foods containing "not added" or "naturally occurring"14 substances are not to be considered adulterated unless the FDA shows that the presence of the substance renders the food "ordinarily injurious to health."15 "Added" poisonous or deleterious substances are to be deemed unsafe, and the food in which they are present adulterated, if the FDA shows that the substance "may render [the food] injurious to health." ${ }^{16}$ Section $406,{ }^{17}$ however, specifically requires that the FDA consider the practicality of removing an added substance from the food, and permits the establishment of tolerances for substances that are essential in food production or that cannot be avoided through good manufacturing practice.

In order to increase the Act's effectiveness in protecting the public health, Congress in 1958 enacted the Food Additives Amendment. ${ }^{18}$ The Amendment sets up an independent framework in section $409^{19}$ for the regulation of "food additives," as defined in section 201(s) of the Act. ${ }^{20}$ The provisions of sections 402 and 406, regulating

${ }^{13}$ Id.

14 "Naturally occurring" is not a statutory term. It is a term used by the FDA as synonomous with "not an added substance." See, e.g., 39 Fed. Reg. 42743 (1974).

is $\S 402(a)(1), 21$ U.S.C. $\S 342(a)(1)(1970)$.

16 The FDA has the burden of proving a chemical unsafe under the "poisonous and deleterious" provisions of the Act. See T. Christopher \& W. Goodrich, Cases aNd Materials on Food and Drug Laws 531 (1973).

1721 U.S.C. $\S 346$ (1970). Section 406 provides:

Any poisonous or deleterious substance added to any food, except where such substance is required in the production thereof or cannot be avoided by good manufacturing practice shall be deemed to be unsafe for purposes of the application of clause (2) (A) of section 342(a) of this title; but when such substance is so required or cannot be so avoided, the Secretary shall promulgate regulations limiting the quantity therein or thereon to such extent as he finds necessary for the protection of public health, and any quantity exceeding the limits so fixed shall also be deemed to be unsafe for purposes of the application of clause (2) (A) of section 342(a) of this title. While such a regulation is in effect limiting the quantity of any such substance in the case of any food, such food shall not, by reason of bearing or containing any added amount of such substance, be considered to be adulterated within the meaning of clause (1) of section 342 (a) of this title. In determining the quality of such added substance to be tolerated in or on different articles of food the Secretary shall take into account the extent to which the use of such substance is required or cannot be avoided in the production of each such article, and the other ways in which the consumer may be affected by the same or other poisonous or deleterious substances.

is Food Additives Amendment of 1958, Pub. L. No. 85-929, 72 Stat. 1784.

1021 U.S.C. $\S 348(1970)$.

${ }^{20} 21$ U.S.C. $\S 321(\mathrm{~s})$ (1970). Section 201(s) provides in relevant part:

The term "food additive" means any substance the intended use of which results or may reasonably be expected to result, directly or indirectly, in its becoming a component or otherwise affecting the characteristics of any food (including any substance 
"added" substances, remained in the Act; "added substance" and "food additive" are not synonymous terms.

Section 409(a) provides that a food additive shall be considered unsafe within the meaning of Section 402, and therefore adulterated, unless a regulation is in effect that prescribes the permissible terms of its use. ${ }^{21}$ The procedures and standards governing the issuance of such regulations are detailed in subsections (b) through (h) of section 409. Ordinarily a petition proposing a regulation will be filed under section 409 (b) by the manufacturer of the additive. ${ }^{22}$ Reports of investigations "made with respect to the safety for use of such additive" must be included in the petition..$^{23}$ The statute requires the FDA to issue a regulation or deny the petition. ${ }^{24}$ Section 409(c)(3) provides, in part:

(3) No such regulation shall issue if a fair evaluation of the data before the Secretary-

(A) fails to establish that the proposed use of the food additive, under the conditions of use to be specified in the regulation, shall be safe: Provided, That no additive shall be deemed safe if it is found to induce cancer when ingested by man or animal, or, if it is found, after tests which are appropriate for the evaluation of food additives, to induce cancer in man or animal . . . .

intended for use in producing, manufacturing, packing, processing, preparing, treating, packaging, transporting, or holding food; and including any source of radiation intended for any such use), if such substance is not generally recognized, among experts qualified by scientific training and experience to evaluate its safety, as having been adequately shown through scientific procedures (or, in the case as [sic] a substance used in food prior to January 1, 1958, through either scientific procedures or experience based on common use in food) to be safe under the conditions of its intended use. . . .

2121 U.S.C. $\S 348$ (a) (1970). Section 408(a) provides:

A food additive shall, with respect to any particular use or intended use of such additives, be deemed to be unsafe for the purposes of the application of clause (2) (C) of section 342 (a) of this title, unless-

(1) it and its use or intended use conform to the terms of an exemption which is in effect pursuant to subsection (i) of this section; or

(2) there is in effect, and it and its use or intended use are in conformity with, a regulation issued under this section prescribing the conditions under which such additive may be safely used.

While such a regulation relating to a food additive is in effect, a food shall not, by reason of bearing or containing such an additive in accordance with the regulation, be considered adulterated within the meaning of clause (1) of section 342(a) of this title.

22 FDCA $\S 409$ (b)(1), 21 U.S.C. $\S 348($ b)(1) (1970), provides that "any person" may file a petition. The Secretary may propose a regulation on his own initiative. 21 U.S.C. $\S 348(\mathrm{~d})$ (1970).

23 FDCA $\S 409(b)(2)(E), 21$ U.S.C. $\S 348(b)(2)(E)(1970)$.

${ }^{24}$ FDCA $\S 409$ (c)(1), 21 U.S.C. $\$ 348(c)(1)$ (1970).

${ }^{25} 21$ U.S.C. \& 348(c)(3)(A) (1970). 
The general safety clause contained in subsection (c)(3)(A) places the burden of establishing the safety of a chemical on the proponent of the regulation. ${ }^{26}$ The safety clause has generally been construed to incorporate a risk-benefit standard: the FDA must determine whether "the benefits which the chemical produces outweigh the costs of its restricted use."27 Section 409(c)(4) ${ }^{28}$ authorizes the FDA to promulgate regulations that establish the maximum quantity of a substance that may be used in food. Since it is generally recognized that many toxic substances may be safely used in low dosages, ${ }^{29}$ the setting of such tolerances is consistent with the general safety standard.

The anticancer proviso to the general safety claus $\mathrm{e}^{30}$ provides that carcinogenic substances are to be regulated under a standard different from that under which other toxic additives are regulated. ${ }^{31}$ There are essentially two related differences between the respective standards of the safety and anticancer clauses. First, the anticancer clause does not permit risk-benefit analysis; the clause has been interpreted "to prohibit the use of any additive which under any conditions induces cancer in any strain of test animal." 32 The preclusion of risk-benefit balancing reflects a categorical congressional judgment that no benefits outweigh the health risks posed by the presence in food of carcinogenic food additives. Second, the language of the anticancer clause forecloses the setting of tolerance levels for carcinogenic additives. This important difference between the safety and anticancer clauses reflects the lack of a known threshold below which a safe tolerance for a carcinogenic

${ }^{26}$ The Act is silent as to burdens of proof, but support for the position that the manufacturer is to be allocated the burden is found in both the legislative history and the Administrative Procedure Act. Congress intended the Food Additives Amendment to require the processor of a new and unproven additive to prove that ingestion of the substance by human beings was safe. S. Rep. No. 2422, 85th Cong., 2d Sess. 2 (1958). Section 7(d) of the Administrative Procedure Act, 5 U.S.C. $\S 556(d)$ (1970), states that "[e]xcept as otherwise provided by statute, the proponent of a rule or order has the burden of proof." Since the statute requires the manufacturer to petition for approval of an additive, the manufacturer is the proponent of such a regulation. See also 21 C.F.R. § 12.87(d)-(e) (1977).

${ }^{27}$ Hess \& Clark, Div. of Rhodia, Inc. v. FDA, 495 F.2d 975, 993-94 (D.C. Cir. 1974).

${ }^{28} 21$ U.S.C. $\$ 348(\mathrm{c})(4)$ (1970).

29 See generally T. Loomis, Essentials of Toxicology 13 (1975); W. Lowrance, OF ACCEPtable Risk: Science and the Determination of SAFETY 39 (1976).

30 $\S 409$ (c)(3)(A), 21 U.S.C. $\S 348(\mathrm{c})(3)(\mathrm{A})$ (1970) (quoted in text at note 25 supra).

31 The anticancer clauses in the Act were modeled after the recommendations of a symposium held by the International Union Against Cancer in August 1956. See Report of Symposium on Potential Cancer Hazards from Chemical Additives and Contaminants to Foodstuffs, 13 ACTA UNIO Internationales Contra Cancrum 170, 188 (1957).

${ }^{32}$ Bell v. Goddard, 366 F.2d 177, 181 (7th Cir. 1966). 


\section{substance can be assumed. ${ }^{33}$}

After the enactment of the Food Additives Amendment, Congress adopted the Color Additive Amendment of $1960,{ }^{34}$ and the Animal Drug Amendments of $1968 .^{35}$ These amendments establish 1960:

Secretary Flemming stated during testimony on the Color Additives Amendment of

The clause is grounded on the scientific fact of life that no one, at this time, can tell us how to establish for man a safe tolerance for a cancer-producing agent . . . .

So long as the outstanding experts in the National Cancer Institute and the Food and Drug Administration tell us that they do not know how to establish with any assurance at all a safe dose in man's food for a cancer-producing substance, the principle in the anticancer clause is sound.

Color Additives: Hearings before the House Comm. on Interstate and Foreign Commerce, 86th Cong., 2d Sess. 501 (1960) [hereinafter cited as Color Additive Hearings].

It is not simply the absence of data indicating how much or how little of a carcinogen will produce cancer in human beings that supports the no-threshold hypothesis. These positive findings, as summarized by the World Health Organization Scientific Group, support the theory:

(1) the self-replicating nature of the cancer cell;

(2) the work of Druckrey and others, which has been interpreted to indicate summation of irreversible effects in carcinogenesis (this has been expressed by Druckrey in the equation $D t n=K^{3}$ where $n$ is greater than 1 );

(3) evidence from experiments on tumour initiation and promotion in skin carcinogenesis indicating lasting change induced by one tumour-initiating event;

(4) the fact that cancer can occur in response to chemicals, even after single doses, long after their disappearance from the body;

(5) the possibility that cancer may result from mutation in a somatic cell.

World Health Organization, Assessment of the Carcinogenicity and Mutagentcity of Chemicals 9-10 (Tech. Rep. Ser. No. 546, 1974).

The equation in (2) indicates that the mean latency period for a tumor to develop is inversely proportional to the amount of total dosage. If the equation is confirmed by experimental methods, it suggests that even extremely small doses can induce tumors in a sufficiently long period of time. However, it is possible that the length of time necessary for the tumor to develop would extend beyond the life span of the organism. See Druckrey \& Schmähl, Quantitative Analyse der experimentellen Krebserzeugung, 49 DIE NATURwissenSchaften 217 (1962). See also J. Arcos, M. Argus \& G. Wolf, Chemical Induction of Cancer 436-38 (1968); P. Daudel \& R. Daudel, Chemical Carcinogenesis and Molecular Biology 135 (1966).

The WHO Scientific Group also discussed the support for the existence of a threshold. The possibility that the cancer-inducing event is reversible is supported by the decline in the risk of developing lung cancer in ex-smokers. Cellular mechanisms for the repair of DNA may result in the correction of the cancer-initiating event. The possibility also exists that a single tumor cell may be eliminated by immunological mechanisms. For further discussion of the merits of basing the anticancer clauses on the principle that no threshold exists for chemical carcinogens, see Health Research Group, Cancer Prevention and the Delaney Clause (1973); Blank, The Delaney Clause: Technical Naivete and Scientific Advocacy in the Formation of Public Health Policies, 62 CaLIF. L. REv. 1084 (1974); Epstein, The Delaney Amendment, 3 Ecologist 424 (1973); Epstein, The Delaney Amendment, 2 Preventive Med. 140 (1973); Oser, An Assessment of the Delaney Clause After 15 Years, 2 Preventrve Med. 150 (1973); Saffiotti, Comments on the Scientific Basis for the Delaney Clause, 2 Preventive Med. 125 (1973); Schneiderman \& Mantel, The Delaney Clause and a Scheme for Rewarding Good Experimentation, 2 Preventive MED. 165 (1973).

is Pub. L. No. 86-618, 74 Stat. 397.

25 Pub. L. No. 90-399, 82 Stat. 342. 
independent frameworks for the regulation of color additives and new animal drugs. Like section 409 , the color additive and animal drug provisions each contain a safety and anticancer clause ${ }^{36} \mathrm{How}$ ever, section $512(\mathrm{~d})(1)(\dot{H})^{37}$-called the DES Amendment because it was enacted to allow the continued use of diethylstilbestrol (DES)-enables the agency to permit the use of carcinogenic animal drugs if no residue of the drug can be found in any edible portion of the treated animal.

\section{Defining a Carcinogen}

One of the most difficult problems in the implementation of the anticancer clause is the very basic one of ascertaining which chemicals are carcinogenic. The Act prohibits the approval of any chemical that "is found to induce cancer when ingested by man or animal, or . . . is found, after tests which are appropriate for the evaluation of the safety of food additives, to induce cancer in man or animal."'38 Three major issues are raised by this definition. The first concerns the meaning of the term "induce"; the second, the required methods of carcenogenicity testing; and the third, the evaluation of test results.

A. The Meaning of "Induce": Primary and Secondary Carcinogens

The verb "induce" ordinarily means "to bring on or to bring about" or "to effect," 39 and there is no indication that Congress intended the term to have a specialized or technical meaning in the anticancer clause. One would expect the clause to apply to any chemical the ingestion of which results in the formation of tumors, regardless of the mechanism by which the formation occurs..$^{40} \mathrm{Nev}$ ertheless, the FDA has in practice distinguished between "primary" and "secondary" carcinogenic effects.

There are basically two kinds of "secondary" carcinogenic ef-

is Color Additive Amendment: FDCA $\$ 402$ (c), 21 U.S.C. $\$ 342$ (c) (1970) (safety clause); FDCA § 706(b)(5)(B), 21 U.S.C. § 376(b)(5)(B) (1970) (anticancer clause).

Animal Drug Amendments: FDCA § 501(a)(5), 21 U.S.C. § 351(a)(5) (1970) (safety clause); FDCA $\S 512(d)(1)(\mathrm{H}), 21$ U.S.C. $\S 360 \mathrm{~b}(\mathrm{~d})(1)(\mathrm{H})(1970)$ (anticancer clause).

${ }^{37} 21$ U.S.C. $\$ 360 \mathrm{~b}(\mathrm{~d})(1)(\mathrm{H})(1970)$.

${ }^{38}$ See text at note 25 supra. The words "carcinogen" and "carcinogenic" are not used in the Act.

39 Webster's Second New International Dictionary 1269 (2d ed. 1956).

so Cf. Bell v. Goddard, 366 F.2d 177, 180-82 (7th Cir. 1966), -in which the court, though not directly facing the issue, drew no distinction between chemicals which "cause" and those which "incite" cancer, and concluded that the clause "is generally intended to prohibit the use of any additives which under any conditions induce cancer . . . ." Id. at 181. 
fects. First, a chemical itself noncarcinogenic may react with chemicals commonly found in food to form carcinogens. Nitrites, which are used as preservatives and are commonly present in cured meat and fish, exemplify this category of secondary carcinogens. Although nitrites themselves do not cause tumors in experimental animals, ${ }^{41}$ studies have shown that under certain conditions nitrites can react with chemical compounds known as amines to form potently carcinogenic nitrosamines. ${ }^{42}$ Amines are present in a wide variety of foods, ${ }^{43}$ and there is evidence that concurrent ingestion of nitrites and the appropriate amine or amide by man may produce the conditions necessary for formation of nitrosamines. Tumors have been induced in animals after concurrent ingestion of nitrites and certain secondary amines, ${ }^{44}$ and one type of nitrosamine was found in the stomachs of human subjects fed a combination of nitrites and amines. ${ }^{45}$

FDA officials have said that the anticancer clause is not applicable to ingested nitrites. They reason that in order for the clause to apply, nitrites must by themselves cause cancer. Under the FDA's view, the anticancer clause would apply only if it were demonstrated that nitrites added to fish or meat produced nitrosamines in the food itself. The clause does not apply, the FDA claims, to nitrites which upon ingestion might react with amines and produce nitrosamines in the body. ${ }^{46}$ Adoption of this restrictive interpretation enabled the FDA to base its proposed regulation of nitrites on the safety clause, and thereby to propose restrictions upon the use of nitrites as an alternative to complete prohibition, ${ }^{47}$ a drastic step the agency was

" See H.R. Rep. No. 1338, 92d Cong., 2d Sess. 9 (1972). See generally E. Williams \& R. Harkins, The Nitrite Controversy 24 (1974) (unpublished Grocery Manufacturers Association monograph). (1970).

${ }^{12}$ See Lijinsky \& Epstein, Nitrosamines as Environmental Carcinogens, 225 NATURE 21

13 Amines or amides are found in a large number of drugs, food additives, and natural products. Although many amines in food can be eliminated, the amines that occur naturally and those produced during the cooking of food cannot. Regulation of Food Additives and Medicated Animal Feeds: Hearings before the Subcomm. on Intergovernmental Relations of the House Comm. on Government Operations, 92d Cong., 1st Sess. 132 (1971) [hereinafter cited as Regulation of Food Additives Hearings].

"See generally H.R. Rep. No. 1338, 92d Cong., 2d Sess. 8 (1972).

45 Magee, Toxicity of Nitrosamines, 9 Food Cos. Toxicologx 215 (1971).

"Regulation of Food Additives Hearings, supra note 43, at 540-41; E. Williams \& R. Harkins, supra note 41 , at $24-27$.

17 The FDA stated that "the use of nitrites and nitrates should be limited to only those uses which are essential in inhibiting the growth of C. botulinum and for obtaining the essential characteristics of cured meats at this time." 37 Fed. Reg. 23457 (1972). The proposed regulation would appear to prohibit the use of nitrites for solely "cosmetic" purposes, i.e., to give meats their red color. For a discussion of whether nitrites are necessary to safeguard against C. botulinum, see H. Wellrord, SOWING THE WIND 176 (1972). 
unwilling to take.48

A chemical may also be considered a secondary carcinogen if it does not directly produce tumors, but instead causes a disruption of some bodily function that in turn induces tumor formation. An example is the animal nutrient selenium. In three of six studies, test animals fed high dosages of selenium developed tumors. ${ }^{19}$ It was found that selenium in high doses produced liver damage in the test animals and that the liver damage was responsible for the development of tumors. The FDA concluded on this evidence that selenium does not induce cancer. ${ }^{50}$ The agency, therefore, regulates selenium under the safety clause and permits use of the chemicals as a nutrient in the feed of poultry and swine at levels that the FDA feels will not endanger human health..$^{51}$

The FDA's position that selenium is safe in low dosages yet dangerous at higher levels might appear to be inconsistent with the premise of the anticancer clauses that no safety threshold for cancer-causing agents can be identified. The agency was careful, however, to justify its action in terms of the purposes of the anticancer clauses. The clauses, it pointed out, "are predicated on the theory that, since we do not know the mechanisms of carcinogenesis, even one molecule of a carcinogen should not be allowed into the food supply." ${ }^{2}$ Where the mechanism is known, however-as the FDA was certain it knew the mechanism by which selenium induced cancer in the test rats-and where it is clear that the mechanism is triggered only by abnormally high dosages,$^{53}$ the reasoning behind

"The Director of the Bureau of Foods has stated that if the FDA were to "carry through the Delaney philosophy, it would mean banning the curing of meat in this country." FooD Chemical News, Sept. 18, 1972, at 26. He stated that at present there is no substitute for nitrites and estimated that about $80 \%$ of the swine meat in the United States is cured with nitrites, amounting to approximately $40 \%$ of the nation's meat supply. Id. Nevertheless, the FDA recently announced its intention to reexamine the use of nitrites in poultry, and the agency's Chief Counsel stated that it would not search for "legal mechanisms for saving nitrites." Food Chemical News, May 16, 1977, at 3.

s3 38 Fed. Reg. 10458, 10459-60 (1973).

so The Commissioner was of the opinion that:

The anticancer clauses do not apply in the case of an agent that (1) occurs naturally in practically all foods, (2) is used in a manner such that the natural level in food is not increased, (3) has a definite hepatotoxic effect/no-effect level, and (4) has a possible carcinogenic effect which is associated only with the hepatotoxic effect.

38 Fed. Reg. 10460 (1973). The "hepatotoxic effect" referred to is liver damage.

st 21 C.F.R. \& 573.920 (1977).

5238 Fed. Reg. 10460 (1973).

ss There. is a general controversy as to whether the use of a very high dosage results in an increased incidence of tumors because of stress, alteration of the hormonal balance, or overloading of the metabolic pathways. See, e.g., Weil, Guidelines for Experiments to Predict the Degree of Safety of a Material for Man, 21 Toxicology \& Applied Pharmacology 194 
the anticancer clauses does not apply.

The rationale of the selenium decision could become a significant loophole in the Delaney policy if not applied with great care. In the selenium case the FDA did not spell out in any detail the basis for its conclusions that the hepatotoxic effect identified was attributable solely to the dosage levels, and that the carcinogenic effects were associated only with the hepatotoxic effect. When there is affirmative evidence that an additive, by whatever mechanism, induces cancer when ingested by animals, the FDA should not set tolerances unless it is satisfied beyond doubt that it fully understands the mechanism of carcinogenesis, and that the mechanism can never be triggered in humans by ingestion of any amount of the substance that could conceivably reach humans. Such a standard will seldom be satisfied in practice. ${ }^{54}$

The FDA perhaps had little choice in the selenium case because selenium must remain on the market. Selenium in low doses is essential for normal growth and metabolism in animals, ${ }^{55}$ and animals cannot produce it endogenously. The agency's treatment of selenium illustrates the need in some cases to accommodate the facially absolute demands of Delaney with the necessities of food production and processing.

\section{B. Scientific Standards: Testing for Carcinogenicity}

The most difficult task faced by the FDA in the implementation of the anticancer clause is that of determining when the evi-

(1972). The use of high doses has been defended. See, e.g., U.S. Dep't of Health, Education and Welfare, Report of the Advisory Panel on Carcinogenicity, Teratogenicity and Mutagenicity (1969) (quoted in Epstein, The Delaney Amendment, 3 Ecologist 424, 425 (1973)).

st The issue raised by the selenium case has surfaced in connection with FDA's consideration of furazolidone, a new animal drug. In support of a request for a hearing, manufacturers of the drug have cited the selenium decision for the proposition that a chemical shown to increase the incidence of malignant tumors in test animals is not necessarily a carcinogen within the meaning of the anticancer clauses. Rhodia, Inc., Memorandum in Support of Request for Hearing 4, In the Matter of Furazolidone, No. $76 \mathrm{~N}-0172$ (FDA, filed August, 1976). The manufacturers claim that high dosages of furazolidone disrupt the hormonal balance of rats and that the resulting imbalance, in turn, induces cancer. 41 Fed. Reg. 19907, 19911 (1976). In its Notice of Opportunity for Hearing on the proposal to withdraw approval of furazolidone, the Director of the Bureau of Veterinary Medicine of the FDA, after noting that the claimed hormonal effect was not supported by the evidence, stated:

Even if a hormonal effect had been adequately demonstrated and established as the sole operant in the development of mammary tumors in the female rats studied, the mechanism would have to be sufficiently defined. Then, if the mechanism in rodents was not applicable to humans, it would be necessary to determine that the nitrofurans would not cause a different hormonal effect in humans by using an appropriate animal species to establish a "no-hormonal-effect" level.

Id. at 19912. Such skepticism is appropriate, yet was noticeably absent in the selenium case. s5 See generally National. ACademy of Sciences, Selenium in Nutrition (1971). 
dence of a chemical's carcinogenic effects is sufficiently strong to warrant labeling the chemical a carcinogen. If a hypothetical chemical produced malignant neoplasms in one hundred per cent of the test animals treated with the chemical while none of the control animals developed malignancies, the inference that the chemical "induces cancer" would be irresistible, assuming reproducible, wellperformed, and well-controlled experiments. It is not surprising, however, that virtually none of the evaluations performed by the FDA has been as simple and unequivocal as the hypothetical case. Most have provoked prolonged and at times bitter disputes, ${ }^{56}$ in part because there has seldom been scientific agreement on the validity of the tests employed, or the significance of the test results. ${ }^{57}$ The FDA has never promulgated standards for determining whether a chemical is a carcinogen. ${ }^{58}$

se See Hutt, A Regulator's Viewpoint, in National Academy of Science, How Safe Is Safe? The Design of Policy on Drugs and Food Addrtives 116 (1974).

${ }^{57}$ Scientists' difficulty in agreeing on the carcinogenicity of a chemical is evidenced by the 1976 Summary Statement of the Temporary Committee for the Review of Data on Carcinogenicity of Cyclamate:

The Committee concludes that the present evidence does not establish the carcinogenicity of cyclamate or its principal metabolite, cyclohexylamine, in experimental animals. No conclusion could be reached concerning the question of cyclamate's potential carcinogenicity in humans due to the short post-exposure observation time, the insensitivity of epidemiologic studies to detect relatively small changes in cancer incidence, and other factors.

The Committee expresses concern over the statistically significant increase in tumors in cyclamate-treated animals from several studies; however, the interpretation of these results is confounded by the nature of the test procedures or animal strain employed. The presence of tumors of the urinary tract in other animal studies, though not in statistically significant numbers, is cause for additional concern.

The Committee notes the relatively limited sensitivity of current bioassay systems. Although no chemical can be proven unequivocally to lack carcinogenicity with these systems, one with a significant carcinogenic hazard for humans could escape detection. Div. of Cancer Cause \& Prevention, Nat'l Cancer Inst., Report of the Temporary Committee for the Review of Data on Carcinogenicity of Cyclamate 1 (1976) [hereinafter cited as Cyclamate Report].

5x Throughout the literature there can be found fragmentary suggestions of what such standards could be. See, e.g., FDA Advisory Committee on Protocols for Safety Evaluation, Panel on Carcinogenesis Report on Cancer Testing in the Safety Evaluation of Food Additives and Pesticides, 20 Toxicology \& Applied Pharmacology 419 (1971) (never officially adopted by the FDA). In discussion of a recent regulation, the Commissioner recommended that the Report of the Panel on Carcinogenesis serve as guidance in developing laboratory protocols. 42 Fed. Reg. 10412, 10417-18 (1977).

The procedure for the evaluation of certain animal drugs has been discussed by FDA officials in a paper presented at a scientific symposium. See Kolbye \& Perez, Human Safety Considerations From the Use of Anabolic Agents in Food Producing Animals (1975) (unpublished paper presented at FAO/WHO Symposium on the Use of Anabolic Agents in Animal Production and Its Public Health Aspects, held March 17-19, 1975, in Rome).

An attempt to promulgate toxicological criteria for additives in 1971 was unsuccessful. 
1. Appropriate Tests. The Act gives the FDA broad discretion in determining the testing methods to be employed. Carcinogenicity can be determined by testing via ingestion by man or animal, ${ }^{59}$ or by other "appropriate" tests not involving ingestion at all. The induction of a neoplasm following exposure to a chemical carcinogen is poorly understood; ${ }^{60}$ the processes by which cancer results from the incorporation of suspected carcinogens in an animal's diet is obscured by the play of numerous inherent variables. ${ }^{61}$ These difficulties have led to much dispute concerning the validity of individual testing techniques, and a number of basic issues remain unresolved.

The first hurdle is to identify those chemicals that require longterm testing. Adequate testing requires that experimental animals be treated with the compound over their life span-a timeconsuming and costly procedure. ${ }^{62}$ Consequently, a great number of chemicals used in food have not been tested for carcinogenicity. ${ }^{63} \mathrm{It}$

See Food Chemical News, May 10, 1971, at 17. The need for such standards has been conceded publicly by one FDA official. Food Chemical NEws, Sept. 8, 1975, at 10.

The FDA has recently announced the development of criteria for evaluating the safety of flavoring substances used as food ingredients. The criteria are contained in a technical report prepared under contract for the Bureau of Foods, FDA, by the ad hoc Select Committee on Flavor Evaluation Criteria of the Life Sciences Research Office, Federation of American Societies for Experimental Biology. The criteria have not yet been officially adopted. See 42 Fed. Reg. 10065 (1977).

The FDA has issued guidelines for the chemical and technological requirements of food additive petitions. They summarize requirements dealing with such subjects as the chemical identity and assay methods of proposed compounds. The guidelines, however, do not set forth any requirements for safety testing. Bureau of Science, FDA, FDA Guidelines for Chemistry and Technology Requirements of Food Additive Petitions (Aug. 1966).

5) The recognition that useful toxicologic screening could be accomplished in species other than man was based upon a report submitted to the Congress by the National Cancer Institute. Mider, The Role of Certain Chemicals and Physical Agents in the Causation of Cancer, in Color Additive Hearings, supra note 33, at 45, 53.

io See S. Robbins, Pathologic Basis of Disease 134 (1974).

"See generally Canada Ministry or Health \& Welfare, The Testing of Chemicals for Carcinogenicity, Mutagenicity and Teratogenicity (1973). The inherent variables include nutritional, endocrinal, immunological, genetic, and environmental factors. The difficulties that these variables pose for the regulator in identifying a carcinogen were recognized soon after the passage of the Food Additive Amendments of 1958. See, e.g., President's Science Advisory Committee, Report of the Panel on Food Additives (1960).

22 See generally Peck, Design of Experiments to Detect Carcinogenic Effects of Drugs in Carcinogenesis Testing of Chemicals 1 (L. Golberg ed. 1974). The cost of testing one chemical for carcinogenesis in one species averages approximately $\$ 75,000.00$. Gehring, Rowe \& McCollister, Toxicology: Cost/Time in 1 Dow Chemical Co., Chemicals, Human Health and THE ENVIRONMENT 32, 38 (1975).

w See National Advisory Food and Drug Committee, FDA, Transcript of Proceedings of June 29-30, 1976, at 2-54 (remarks of Alexander Schmidt, Commissioner, FDA). See generally Comptroller General Report, Federal Efforts to Protect the Public from Cancer-Causing Chemicals Are Not Very Effective (June 16, 1976). 
has been estimated, for example, that only twenty per cent of the new animal drugs approved by the FDA have undergone long-term testing. ${ }^{64}$

Full implementation of the anticancer clause would involve long-term testing of all substances submitted for FDA approval. The FDA, however, cannot conduct the tests itself, and is apparently unwilling to impose such a heavy burden on manufacturers. ${ }^{65}$ Even if long-term testing of all chemicals cannot realistically be required, the FDA should avoid hit-or-miss application of the clause, perhaps by adopting guidelines for the determination of which chemicals require long-term testing. ${ }^{60}$ This problem might be alleviated by the recent development of short-term in-vitro tests ${ }^{67}$

"FDA Toxicology Advisory Committee, Minutes of Meeting, (Oct. 4, 1976) at 5 [hereinafter cited as Toxicology Committee].

${ }^{65}$ The Act does not expressly set forth any testing requirement, nor does it specify how the FDA is to obtain the experimental data upon which to base its regulations. However, the Food Additives Amendment does require that full reports of any investigations made with respect to the safety of a chemical be included in a food additive petition. FDCA $\$$ 409(b)(2)(E), 21 U.S.C. § 348(b)(2)(E) (1970). See also FDCA § 409(c)(3), 21 U.S.C. § 348(c)(3) (1970) (requiring a "fair evaluation of the data before the Secretary"). Thus, the Secretary determines what tests are adequate to document a chemical's safety. Since the Act dictates that the manufacturer of a new chemial bear the burden of proving the chemical's safety, see note 26 supra, the manufacturer is effectively compelled to conduct the required test or the Secretary will deny the food additive petition.

In practice, most testing is conducted by the manufacturer. Legislation has been proposed which would require third-party testing of food chemicals by independent testing laboratories. See 119 Cong. Rec. 1174 (1973). See generally Nat'l Cancer Inst., Report of the Director's ad hoc Committee on Testing for Environmental Chemical Carcinogens (Aug. 1973) (unpublished report, National Cancer Inst.) [hereinafter cited as Director's Report]. The FDA does in fact test a few substances itself. See Ad hoc Committee on Testing for Environmental Chemical Carcinogens, Minutes of Meetings of May 31 and June 1, 1973, in Director's Report, at 4-5.

"The FDA has not set forth any official guidelines. Director's Report, supra note 65, at 1. At a recent FDA Advisory meeting one FDA staff member catalogued the factors generally considered in determining whether long-term testing of animal drugs is required:

Several factors determine whether additional testing of the parent drug is required. If the compound or any residue in food is a suspect carcinogen, lifetime testing in two rodent species is always required. A compound is considered a suspect carcinogen if it is structurally related to known carcinogens or it is expected to be possibly transformed to a known carcinogenic compound when ingested by humans. In addition, the biological activity of a kind sometimes associated with carcinogenicity may categorize a compound as a suspect carcinogen. For example, if it produced thyroid hyperplasia or bile duct proliferation in subchronic studies, then long-term tests are required.

Toxicology Committee, supra note 64, at 6 . The promulgation of guidelines would eliminate the arbitrary results often obtained when regulators simply "eyeball" the data. See Color Additives: Botched Experiment Leads to Banning of Red Dye No. 2, 191 SCIENCE 450 (1976).

${ }^{37}$ One short-term test uses the bacteria Salmonella as an indicator of DNA damage. The test is based on the theory that cancer is caused by mutations. Experimental data indicates a high correlation between carcinogenicity and mutagenicity. In one study $90 \%$ of 175 known carcinogens were mutagenic in the short-term test, including almost all of the known human 
for carcinogenicity screening. If in-vitro testing proves reliable, it would aid greatly in the determination of which compounds should be subjected to long-term animal tests. A program could be instituted under which chemicals yielding positive short-term test results could be approved only after long-term testing. ${ }^{68}$ The FDA could also require manufacturers of chemicals that have been approved without long-term testing to submit to periodic reevaluations and to conduct additional tests if necessary..$^{69}$

There is also great need for the development of guidelines specifying testing conditions. Many FDA evaluations have been based on a multitude of different experiments conducted under different circumstances. Few if any of the individual studies have been reproduced. ${ }^{70}$ The necessity for guidelines would be diminished if the results of these different tests were somewhat uniform. In fact, however, results of these experiments have varied greatly. ${ }^{\text {" Such guide- }}$ lines cannot be promulgated, however, until certain policy decisions are made regarding the desired degree of anticancer effort. It is well documented that certain testing procedures are more sensitive than others, in the sense that certain tests are more likely than others to yield a positive result. ${ }^{22}$ For example, carcinogenicity tests using the transplacental route of administration, whereby testing is begun in the parent generation and carried over to the newborn generation, appear to be more sensitive than other test systems. ${ }^{73}$ Some experts

carcinogens. See McCann \& Ames, Detection of Carcinogens as Mutagens in the Salmonella/Microsome Test: Assay of 300 Chemicals, 73 Proc. Nat'l Acad. Scr. 950 (1976). The test is simple, inexpensive, and fast. See Food Chemical News, Feb. 14, 1977, at 2.

"Such an approach is suggested in Subcomm. on Environmental Carcinogenesis, Nat'l Cancer Advisory Bd., General Criteria for Assessing the Evidence for Carcinogenicity of Chemical Substances (June 2, 1976) (unpublished report, U.S. Dep't of Health, Education, and Welfare).

" Although not specifically authorized by the Act, such conditional regulations should be within the scope of the FDA's broad rulemaking power under FDCA $\S 701$ (a), 21 U.S.C. $\S$ 371(a) (1970). This seems to be the purpose of the cyclic review procedures that FDA is developing. See Food ChEMicAL News, Oct. 11, 1976, at 20.

it The evaluation of the carcinogenicity of saccharin conducted by the National Academy of Sciences for the FDA was based on eleven different studies. Food and Nutrition Bd., Nat'l Research Council, Safety of Saccharin and Sodium Saccharin in the Human Diet (1974) (unpublished report, National Academy of Sciences).

Evaluation of cyclamate by the National Cancer Institute for the FDA was based on twenty-five different studies. See Cyclamate Report, supra note 57.

"See, e.g., Cyclamate Report, supra note 57 (nineteen studies on cyclamate with negative results; six studies with positive or inconclusive results).

72 There are many factors which may affect the sensitivity and results of a test. Such factors include the route of administration, dosage, frequency of exposure, strain of animal, species, age, diet, immunological status, and duration of the experiment. See CANADA MinisTRY OF HEALTH \& WELFARE, supra note 61.

${ }^{73}$ See Shubik, Interpretation of Test Results in Terms of Significance to Man, in 
have advocated the use of the most sensitive test; ${ }^{74}$ others have urged that the testing mimic conditions of human consumption as much as possible. ${ }^{75}$ The former position would seem more consistent with the policy of the anticancer clause, although the use of an extremely sensitive test raises the risk that the carcinogenic effects discovered may be the product of the experimental design. ${ }^{76}$ In any event, the issue must be squarely faced as a prerequisite to the promulgation of any guidelines.

Although the adoption of test guidelines need not foreclose reliance upon other relevant data, there is a danger that such guidelines might discourage the pursuit of other lines of research aimed at developing improved methods of carcinogenicity testing. ${ }^{77}$ The likelihood of that danger materializing, however, would be small-any guidelines adopted must of course be subject to continuous review, and university laboratories and medical centers would be under no compulsion to restrict their work. In addition, should tests conducted under the prescribed guidelines indicate that a chemical is hazardous, the manufacturer would have an incentive to disprove those findings, and, in the process, conceivably might develop new and more accurate testing methods.

The promulgation of test guidelines would serve at least three purposes. First, tests conducted according to standardized procedures would be more easily reproducible. Reproducibility would help to eliminate unreliable data. ${ }^{78}$ Second, guidelines would inform manufacturers of the kind of testing that must be conducted. By instructing the manufacturers that the use of certain tests will enhance the chances for approval, the FDA could increase industry incentives to test chemicals adequately ${ }^{79}$ Equally important, guide-

Carcinogenesis Testing of Chemicals 45 (L. Golberg ed. 1974).

${ }^{73}$ E.g., Chemicals and the Future of Man: Hearings before the Subcomm. on Executive Reorganization and Government Research of the Senate Comm. on Government Operations, 92d Cong., 1st Sess. 44, 50 (1971) (statement of Dr. S. Epstein) [hereinafter cited as Epstein Statement].

75 See, e.g., Weil, supra note 53.

"See text and notes at notes 51-54 supra.

77 See E. Burger, Protecting the Nation's Health 6 (1976); Food Chemical News, Sept. 8, 1976, at 10 .

2x For a discussion of the importance of reproducibility in carcinogenesis testing, see Subcomm. on Environmental Carcinogenesis, Nat'l Cancer Advisory Board, Transcript of Proceedings at 50-90 (March 3, 1976).

7O One industry counsel has remarked:

Without a more carefully defined criteria, we are like players in a ball game where new rules are imposed as the game progresses and the referees impose penalties for that which was not a violation when the game started.

M. Sayer, Food Regulation: Quo Vadis 4 (Jan. 20, 1976) (unpublished paper presented at the 
lines would better enable manufacturers to determine the costs of safety approval at an early developmental stage. ${ }^{80}$ Third, standardized testing would streamline the approval process and would help the FDA cope with the vast number of untested chemicals now on the market. Although there are dangers attendant upon the use of testing guidelines, such guidelines are, as a practical matter, essential to the full and efficient implementation of the anticancer clauses. ${ }^{81}$

2. Evaluation of Data. The anticancer clause of section 409 provides that "no additive shall be deemed safe if it is found to induce cancer ...."82 The anticancer clause, therefore, applies only if there is affirmative evidence that the chemical induces cancer. ${ }^{83}$ The mere fact that the chemical may produce tumors in certain test animals does not conclusively establish carcinogenicity. ${ }^{84}$

New York State Bar Association Annual Meeting, Food, Drug \& Cosmetic Law Section) (on file with the University of Chicago Law Review).

- See Epstein Statement, supra note 74, at 57.

" The National Cancer Institute has developed a comprehensive protocol for carcinogenesis testing, Nat'l Cancer Institute, Guidelines for Carcinogen Bioassay in Small Rodents (Tech. Rep. Ser. No. 1, NCI-C6-TR-1, February, 1976). Since these guidelines are general in nature (they may apply to occupational, environmental, and experimental carcinogens), they may not be suitable in all respects for application to food additives.

${ }^{22} 21$ U.S.C. $\& 348(\mathrm{c})(3)(\mathrm{A})$ (1970).

23 If there is some evidence that an additive might be carcinogenic but that evidence does not warrant concluding that the additive "induces cancer," the safety of the additive would be evaluated under the standards of the safety clause. Two recent FDA withdrawals of suspected carcinogens were based on the safety clause-the withdrawal of the food additive diethylpyocarbonate (DEPC), theoretically capable of combining with other ingredients to form the carcinogen urethan, 37 Fed. Reg. 3060, 15426 (1972); and the withdrawal of mercaptoimidazoline, a compound which could possibly rearrange chemically to form ethylenethiourea, a carcinogen. 38 Fed. Reg. 10116, 33072 (1973). According to the FDA, neither action was based on the anticancer clause because the scientific evidence indicated only a possibility that the compounds were carcinogenic. See FDA, Evolution of Chemical Analysis in Relation to the Regulation of Foods, Drugs and Cosmetics in Agriculture-Environmental and Consumer Protection Appropriations for 1975, Hearings before the Subcomm. on AgricultureEnvironmental and Consumer Protection of the House Comm. on Appropriations, 93d Cong., 2d Sess., pt. 8, at 218 (1975) [hereinafter cited as 1975 Appropriations Hearings].

The application of the safety standard would permit the use of a suspected carcinogen if the expected benefits of its use outweigh the risk that it causes cancer. See Food CHEMICAL News, July 1, 1974, at 10 (discussion of the role of economic benefit considerations in FDA's regulation of carcinogenic substances). To illustrate, if a preservative for which there is no economically realistic substitute is suspected of being carcinogenic, the social utility of its continued use would counsel against its removal from the market; however, if a food color were suspected, the relatively low social utility of its use would not sufficiently counterbalance the risk that it might cause cancer.

s See Color Additive Hearings, supra note 33, at 62 (statement of Secretary Flemming):

It has been suggested that once a chemical is shown to induce a tumor in a single rat, this forecloses further research and forever forbids the use of the chemical in food. This is not true. The conclusion that an additive "is found to induce cancer when ingested 
Unlike scientists who can eschew reliance on insufficient data, ${ }^{85}$ however, the agency must make decisions on the basis of incomplete or inconclusive evidence. ${ }^{86}$

It would be impossible for the FDA to spell out with specificity the quantum of evidence that will suffice for concluding that a chemical is carcinogenic. Nevertheless, the present confusion and uncertainty concerning sufficiency of scientific evidence is at least partly avoidable. The FDA should clarify the criteria for evaluating test results. The difficulties encountered in test evaluation are indeed formidable. Consider, for example, the variety of ways in which chemicals can affect tumorigenesis:

The response to a tumorigenic substance may consist of (1) an increased incidence of tumors of a type commonly seen in the control animals, (2) the development of a type of tumor not seen in the control animals, or (3) a combination of the occurrence of a different type of tumor and an increased incidence of one of several types of tumors seen in controls. In some experiments the only manifestation of an effect consists of (4) an earlier occurrence of tumors in the treated animals than in the controls, the incidence being the same in both. In yet another variation the only effect seen may consist of (5) an increase in the number of tumors per animal, the number of tumor-bearing animals being the same $\ldots{ }^{87}$

Moreover, tumors differ in their structural characteristics-for example, a chemical may cause the formation of histopathologically benign tumors, thus raising the difficult question whether the induction of benign tumors suggests that the chemical is carcinogenic. ${ }^{88}$

by man or animal" is a scientific one. The conclusion is reached by competent scientists using widely accepted scientific testing methods and critical judgment. An isolated and inexplicable tumor would not be a basis for concluding that the test substance produces cancer.

*s The reluctance of scientists to rely on questionable data was evidenced when the Food and Drug Administration's Toxicology Advisory Committee concluded that the experiments on F.D. \& C. Red No. 2 were not of the quality necessary to demonstrate the safety of Red No. 2. Scientists and Bureaucrats: A Clash of Cultures on FDA Advisory Panel, 191 ScIENCE 1244 (1976).

${ }_{\text {k6 }}$ The legislative history of the Food Additives Amendment of 1958 clearly indicates that absolute certainty regarding the safety of a substance is not requisite to its remaining on the market. Reasonable certainty of the chemical's safety will suffice. See S. REP. No. 2422, 85th Cong., 2d Sess. 6 (1958).

${ }^{87}$ D'Aguanno, Interpretation of Test Results in Terms of Carcinogenic Potential and the Test Animal: The Regulatory Point of View, in Carcinogenesis Testing of Chemicals 41 (L. Golberg ed. 1974).

${ }^{\mathrm{Nx}}$ The role that benign tumors play in the progression of tumor growth is unknown. See 
There have been many proposals of methods to systematically determine which tumorigenic effects justify labeling a chemical carcinogenic. ${ }^{89}$ The proposals generally attempt to develop a strict scientific standard for carcinogenicity, and are not necessarily suitable for regulatory decision making. However, the FDA could develop a system of rebuttable presumptions based on its evaluation of the significance of different kinds of tumorigenic effects. ${ }^{90}$ Such a system would facilitate reasoned decision making at the formal hearing level ${ }^{91}$ and would aid judicial review. Perhaps the most important benefit of such a system would be the guidance that it would provide to the FDA staff and the manufacturers in the informal actions that make up the bulk of the FDA's work. ${ }^{92}$

generally L. FouldS, NEOPLASTIC DEVELOPMENT (1969). Some benign tumors appear to remain benign for the lifetime of the host while others diagnosed at one point as benign may later become malignant. I. Berendlum, Carcinogenesis as a Biological Problem 45 (1974). Moreover, the characterization of a particular tumor (as either benign or malignant) may be a difficult task. See, e.g., National Cancer Advisory Board on Environmental Carcinogens, transcript of meeting of Feb. 4, 1976, at 40-69.

* See, e.g., Canada Ministry of Health \& Welfare, supra note 61; Nat'l Cancer Institute Ad Hoc Committee on the Evaluation of Low Levels of Environmental Chemical Carcinogens, Report to the Surgeon Gen. on Environmental Carcinogens (1970), in Chemicals and the Future of Man: Hearings before the Subcomm. on Executive Reorganization and Government Research of the Senate Comm. on Government Operations, 92d Cong., 1st Sess. 180-98 (1971); Advisory Panel on Carcinogenicity of Pesticides, Carcinogenicity of Pesticides, in Report of the Secretary's Commission on Pesticides and Their Relationship to Environmental Health 459-506 (Dec. 5, 1969); FAO/WHO JoINT EXPERT CommitTEE on Food AdDITIves, Evaluation of Carcinogenic Hazards of Food Additives (WHO Tech. Rep. Ser. No. 220, 1961); FDA Advisory Commitee on Protocols for Safety Evaluation, supra note 58 at 419-38; Food Protection Committee, Problems in the Evaluation of Carcinogenic Hazards from the Use of Food Additives (Nat'l Acad. Sci.-Nat'l Resources Council Publication No. 749, Dec. 1959); International Union Against Cancer, Carcinogenicity Testing (UICC Tech. Rep. Ser., vol. 2, I. Berenblum ed. 1969); WHO, Assessment of the CARCINogenicity ANd MUTAGENicity of Chemicals 9-10 (Tech. Rep. Ser. No. 546, 1974); WHO, Prevention of Cancer, (Tech. Rep. Ser. No. 276, 1964); WHO, Scientific Group, Principles for the Testing and EvaluaTion of Drugs for Carcinogenicity (Tech. Rep. Ser. No. 426, 1969).

"The authority to develop and implement such principles can be inferred from FDCA $\S 409(\mathrm{c})(5)(\mathrm{C}), 21$ U.S.C. $\S 348(\mathrm{c})(5)(\mathrm{C})(1970)$, and FDCA $\S 701(\mathrm{a}), 21$ U.S.C. $\S 371(\mathrm{a})$ (1970).

" Only one formal hearing has been held by the FDA in its attempts to remove carcinogens from the market. See In the Matter of "Tend-A.Wate" (paste containing $15 \mathrm{mg}$. diethylstilbestrol per $0.2 \mathrm{cc}$ ), No. FDC-D-49 (FDA, March 10, 1961). A number of hearings will soon be held regarding other possible carcinogens. See 41 Fed. Reg. 1804, 52105 (1976) (DES); 41 Fed. Reg. 29896 (1976) (F.D. \& C. Red No. 2); 41 Fed. Reg. 19906 (1976) (furazolidone).

Determining the appropriate standards to measure a chemical's safety will be an issue in all of these hearings. See Petitioner's Memorandum on Burden of Proof at 3, In the Matter of F.D. \& C. Red No. 2, No. 76C-0033 (FDA, filed Aug. 23, 1976).

2 "During fiscal year 1975, FDA received 176 food additive petitions and took 197 actions (some prior year carry-over)." Regulatory Reform-Vol. II: Federal Power Commission, Food and Drug Administration: Hearings before the Subcomm. on Oversight and Investigations of the House Comm. on Interstate and Foreign Commerce, 94th Cong., 1st Sess. 407 (1976). 
The opinion of the D.C. Circuit in the case of Environmental Defense Fund v. Environmental Protection Agency ${ }^{93}$ suggests the propriety-and desirability - of such standards. The Environmental Protection Agency, an agency similarly involved in carcinogenicity testing, has developed certain cancer principles ${ }^{94}$ to aid it in assessing the risks posed by environmental carcinogens. Although the EPA's principles have been subjected to criticism, ${ }^{95}$ the court in Environmental Defense Fund held that the Agency may properly rely upon such principles. Rejecting the argument "that the "cancer principles' that EPA relied on improperly biased the agency's openminded consideration of the evidence," ${ }^{96}$ the court noted that the manufacturer had been afforded ample opportunity to rebut the presumptions embodied in the cancer principles. ${ }^{97}$ The opinion praised "EPA's specific enunciation of its underlying analytic principles, derived from its experience in the area [since such specificity provides] . . . meaningful notice and dialogue, enhances the ad-

During the same year the FDA received an estimated 2,142 new animal drug applications and completed an estimated 2,251 reviews. Agriculture and Related Agencies Appropriations for 1977: Hearings before a Subcomm. of the House Comm. on Appropriations, 94th Cong., 2d Sess., pt. 5, at 271 [hereinafter cited as 1977 Appropriations Hearings].

Standards are needed to guide the informal adjudicatory process. Courts and commentators have often emphasized the need to structure the exercise of administrative discretion. See, e.g., Environmental Defense Fund, Inc. v. Ruckelshaus, 439 F.2d 584, 598 (D.C. Cir. 1971). See generally K. Davis, Discretionary Justice (1969).

${ }^{93} 548$ F.2d 998 (D.C. Cir. 1976).

94 The following is a partial listing of the principles:

(1) A carcinogen is any agent which increases tumor induction in man or animals.

(2) Well-established criteria exist for distinguishing between benign and malignant tumors; however, even the induction of benign tumors is sufficient to characterize a chemical as a carcinogen.

(5) Carcinogenesis is characterized by its irreversibility and long latency period following the initial exposure to the carcinogenic agent.

(7) The concept of a "threshold" exposure level for a carcinogenic agent has no practical significance because there is no valid method for establishing such a level.

(8) A carcinogenic agent may be identified through analysis of tumor induction results with laboratory animals exposed to the agent, or on a post hoc basis by properly conducted epidemiological studies.

(9) Any substance which produces tumors in animals must be considered a carcinogenic hazard to man if the results were achieved according to the established parameters of a valid carcinogenesis test.

Respondent's Brief, Proposed Findings and Conclusions on Suspension at 31, In re Shell Chemical Co., FIFRA Docket Nos. 145 et al. (EPA, 1974).

${ }^{2}$ See, e.g., Council for Agricultural Science \& Technology, The Environmental Protection Agency's Nine 'Principles' of Carcinogenicity, Report No. 5 in 1977 Appropriations Hearings, supra note 92 , at 412 .

98 548 F.2d at 1006.

${ }^{97}$ Id. 
ministrative process and furthers reasoned agency decisionmaking." "98 The FDA should emulate the imaginative approach taken by the EPA.

\section{The Ambit of the Anticancer Clauses}

At first blush the Act seems to clearly define the domain of the anticancer clauses. The clauses are applicable to food additives, color additives, and new animal drugs. ${ }^{99}$ Several problems have arisen, however, in determining the coverage of the anticancer clauses. The most important of these controversies surrounds the definition of a "food additive". Other significant problems concern two of the statutory exemptions from the food additive definition and the proper interpretation of the DES Amendment.

\section{A. Food Additives: The Problem of Unavoidability}

Food additive is defined in section 201(s) of the Act as "any substance the intended use of which results or may reasonably be expected to result, directly or indirectly, in its becoming a component or otherwise affecting the characteristics of any food." 100

"Id. at 1007.

" It is not at all clear whether the clauses apply to the withdrawal of regulations. In Rossi v. Finch, [1970 Transfer Binder] Food Drug Cos. L. Rep. (CCH) \ 40391 (N.D. Cal.), the court states that "the Delaney Amendment is operative only upon petitions which are filed to determine the safety of new food additives." This reading would seem to foreclose applying the anticancer clause in proceedings to withdraw a food additive regulation. Section 409 , however, permits amendment or repeal of decisions if new evidence exists with respect to the additive. 21 U.S.C. $\$ 348(\mathrm{~h})(1970)$. Although the applicability of the anticancer clause in withdrawal proceedings is not specifically addressed in the statute (the primary concern of Congress being the establishment of a premarketing clearance scheme), this circumstance should not preclude the application of the clause. It would indeed be anomalous if the FDA could weigh the benefits of the use of a carcinogen, or assume a safe tolerance for a carcinogen, merely because the carcinogenic substance had been approved years earlier on the basis of now obsolete testing.

The recognition that scientific standards for determining the safety of food chemicals will change greatly over time has led the FDA to consider periodic reassessments of food and color additives. Food Chrmicat News, Oct. 11, 1976, at 20. With the institution of such procedures, withdrawal of food additive regulations may become more common.

10021 U.S.C. \$ 321(s) (1970). See generally Krinsky, Regulation of Food Additives Never Added: An Odd Mixture of Science and Law, 37 MoNT. L. REv. 198 (1976); Annot., 21 A.L.R. Fed. 314 (1974). In attempting to illustrate the scope of the definition, both the House and Senate Reports listed three categories of additives: intentional, incidental, and accidental. See Senate Comm. on Labor and Public Welfare, Food Additives Amendment of 1958, S. Rep. No. 2422, 85th Cong., 2d Sess. 4-5 (1958) [hereinafter cited as Senate Additives Report]; House Comm. on Interstate and Foreign Commerce, Food Additives Amendment OF 1958, H.R. REP. No. 2284, 85th Cong., 2d Sess. 3-4 (1958). Intentional additives were described as those substances deliberately added to food, and "incidental" additives as those substances not intentionally added, but which may "reasonably be expected" to enter food. 
Substances can enter food in a variety of ways. First, they can be introduced during the manufacturing and processing stages of food production. Second, substances can enter food during storage and distribution; for example, substances can migrate into food from surrounding packaging materials. Third, substances can enter food through the ecological food pyramids as a result of extensive environmental contamination. Finally, adulteration can occur through such natural processes as fungus growth. Substances intentionally used during manufacturing, processing, storage or distribution are usually "food additives," since in most cases it could have been anticipated that the substances would enter the food. ${ }^{101}$ The status of substances that enter food thrcugh environmental contamination or natural processes is more problematic.

In United States v. Ewig Brothers Co., ${ }^{102}$ the Seventh Circuit held that residues of the chemical pesticides DDT and dieldrin found in smoked chubs were food additives within the meaning of the Act. Although the basis for the court's holding is less than clear, ${ }^{103}$ the court appears to have concluded that DDT and dieldrin

SENATE ADDITIVES REPORT at 5. Indirect or incidental additives comprise the largest number of chemicals in food. There are approximately 2,000 regulated indirect additives. See National Science Foundation, Chemicals and Health: Report of the Panel on Chemicals and Health of the President's Science Advisory Committee 67 (1973). It has been estimated that there are approximately 10,000 indirect food additives. See FDA Food Additives Five Year, Program, Indirect Additives Review 2 (FY-77-81, Aug. 3, 1976). The legislators felt that both intentional and incidental additives were included in the statutory definition of food additives. Senate Additives Report at 5. On the other hand, accidental additives"substances which may accidentally get into food, as for example, paints or cleaning solutions used in food processing plants"-were not thought to be within the definition of food additives. Id.

101 The FDA has adopted no standards for determining whether a substance can reasonably be expected to become a component of food. Food CHEMICAL NEws, March 28, 1977, at 4. The FDA has stated that when a chemical is found in a very low level in the food contact article, it may be possible to predict that there is "no reasonable expectation of migration into food based on theoretical considerations peculiar to the particular product and use." 40 Fed. Reg. 40534 (1975). Such language suggests that FDA would consider adopting the theoretical extrapolation method now used in estimating the significance of animal drug residues. See text and notes at notes 161-63 infra. The FDA specifically rejected the use of the method in its regulations of polychlorinated biphenyls, a food additive. Letter from Alan Bennett, FDA Assistant Chief Counsel for Enforcement, to Stephen M. Truitt, reprinted in FooD Chemical News, Oct. 6, 1976, at 16. The Society of the Plastics Industry recently submitted a petition to the FDA proposing the application of the theoretical extrapolation method to packaging materials. See Food Chemrcal NEws, April 4, 1977, at 22-24. If adopted, the proposal would in effect exclude migrants from the definition of food additive if the level of migration is below a specified level.

102502 F.2d 715 (7th Cir. 1974), cert. denied, 420 U.S. 945 (1975) (noted in 21 VILL. L. REv. 140 (1975)).

${ }_{103}$ The case is complicated by the fact that DDT and dieldrin are pesticide residues. Section 402(a)(2)(c) of the Act, 21 U.S.C. $\$ 342(a)(2)(c)$ (1970), contains a proviso to the effect that pesticide residues remaining on processed agricultural products shall not be deemed 
were "incidental" additives because the presence of pesticides in the food could be traced to human agency. Because Congress had not restricted the scope of the term "food additive" to substances deliberately added, ${ }^{104}$ the court reasoned, the pesticides fell within the statutory language. ${ }^{105}$ The implications of the decision are staggering. DDT and dieldrin, both proven carcinogens, ${ }^{106}$ are ubiquitous environmental contaminants that enter food through the ecological food pyramids. ${ }^{107}$ Were the Ewig Brothers decision carried to its logical extreme all foods containing these pesticides-including most foods of animal origin ${ }^{108}$-would be removed from the market by force of law, for the anticancer proviso to section 409 forbids the issuance of a regulation permitting the marketing of carcinogenic food additives.

The FDA, however, has taken the position that it may, under section 406, set tolerance levels for additives the presence of which in food is unavoidable but that do not satisfy the standards for issuance of a regulation under section 409.109 The agency's position cannot be squared with the statute. The tolerance setting provisions of section 406 are brought into operation only by clause (2)(A) of section $402(\mathrm{a})$, which provides that a food shall be deemed adulterated "if it bears or contains any added poisonous or added deleterious substance (other than one which is ... (ii) a food additive . . .) which is unsafe within the meaning of [section 406] . . . ."110

unsafe, notwithstanding $\$ \$ 406$ and 409 of the Act, if the pesticide had been used on the raw agricultural commodity pursuant to a tolerance or exemption granted under $\S 408$. The argument could be made that the proviso constitutes an independent basis for concluding that Congress considered pesticide residues to be food additives, and the opinion is unclear concerning the extent to which the court relied on this inference, $502 \mathrm{~F} .2 \mathrm{~d}$ at 722 . The inference is not compelling; the language of the proviso suggests that it applies only to agricultural products upon which pesticides were intentionally used, not those in which the presence of the residues is due simply to pervasive environmental contamination. See 21 VILL. L. REv. 140, 149-50 (1975); note 114 infra.

104 See note 100 supra.

105 502 F.2d at 722. Accord, United States v. City Smoked Fish Co., No. 33,669 (E.D. Mich. 1970).

${ }^{106}$ Dieldrin is carcinogenic in five strains of mice and probably in the rat. See Environmental Defense Fund, Inc. v. Environmental Protection Agency, 510 F.2d 1292 (D.C. Cir. 1975).

DDT is also carcinogenic in mice. See Innes, Bioassay of Pesticides and Industrial Chemicals for Tumorigenicity in Mice: A Preliminary Note, 42 J. NAT'L CANCER INST. 1101 (1969); Kemeny \& Tarian, Investigations on the Effects of Chemically Administered Small Amounts of DDT in Mice, 22 EXPERIENTI 748 (1966).

ion See R. Carson, Silent Spring 30-31 (1962).

10x See Feport of the Secretary's Commission on Pesticides and Their Relationship to Environmental Health, supra note 89, at 14.

in See 39 Fed. Reg. 42743, 42744-45 (1974).

1621 U.S.C. \$ $342(\mathrm{a})(2)(\mathrm{A})(1970)$. 
Food containing food additives, on the other hand, is deemed adulterated if the additive is unsafe within the meaning of section 409.111 The statute establishes an independent scheme for the regulation of food additives; any tolerances for unsafe food additives must be established pursuant to a section 409 regulation. ${ }^{112}$ The anticancer clause in section 409 , of course, flatly forbids the Secretary to issue a regulation permitting the use of carcinogenic food additives..$^{133}$

It does not appear, however, that Congress intended to include environmental contaminants not used by the manufacturer or processor within the definition of food additives. ${ }^{114}$ Section 201 (s) de-

III 21 U.S.C. $\$ 342(\mathrm{a})(2)(\mathrm{C})(1970)$.

112 The Supreme Court faced a similar issue in Flemming v. Florida Citrus Exchange, 358 U.S. 153 (1958). In that case processors claimed that $\$ 406$ authorized the Secretary to establish tolerances for the use of coal tar colors upon oranges, even if the colors in question were not certified harmless as then required by $\S 402$ (c) of the Act. The Court rejected this claim. The tolerance setting authority of $\$ 406$, the Court ruled, did not permit the Secretary to establish tolerances for uncertified food colors in the teeth of the $\S 402(\mathrm{c})$ prohibition against the use of uncertified colors. Id. at 166.

is See text and notes at notes 30-33 supra.

114 The Ewig Brothers court noted the proviso to $\S 402(\mathrm{a})(2)(\mathrm{C})$ that deals specifically with pesticide residues in processed agricultural commodities, and read this as evidence that the food additive definition is broad enough to include pesticide residues in processed food. Prior to 1958 only raw agricultural commodities could be considered adulterated as a matter of law. Section 408 of the Act, 21 U.S.C. $\$ 346$ a (1970), permits the setting of tolerances for residues in the raw agricultural commodity. In 1958 the per se concept was extended by the Food Additives Amendment. The purpose of the proviso to $\S 402(a)(2)(C)$ was to extend the tolerance prescribed for the raw commodity to the processed commodity, by providing that residues in processed commodities shall not be deemed unsafe "if . . the concentration of such residue in the processed food when ready to eat is not greater than the tolerance prescribed for the raw agricultural commodity." 21 U.S.C. \& 342(a)(2)(C) (1970). In the court's view, the fact that this proviso was needed is evidence that Congress felt that pesticide residues in the processed commodity were food additives within the meaning of $\S 409$ : in the absence of special provision allowing the marketing of processed commodities containing pesticide residues, such commodities would be subject to per se treatment under $\S 409$.

Even if Congress felt that residues in a processed commodity of pesticides used "in or on" the raw commodity were food additives, however, it does not follow that all pesticide residues in any food commodity are food additives, regardless of the means by which the residue entered the processed food. Indeed it is most curious that Congress, if it thought that all pesticide residues in all commodities were food additives, limited the protection of the proviso to those processed commodities which were themselves treated with pesticides in the raw stage. Were all pesticide residues to be considered food additives, the anomaly would arise that processed commodities directly treated with pesticides would be regulated under $\$ 408$, under which the government bears the burden of providing unfitness, while those processed commodities contaminated via the food pyramids could be marketed only after the processor secured a regulation under $\$ 409$. Congress could not have intended to place a heavier burden on the processor of foods not treated with pesticides than on the processor of directly treated foods, for the latter has far greater control over the condition of the commodities he purchases. Although the existence of a problem may be inferred from the congressional response, the failure of Congress to remedy an almost identical problem of vaster implications perhaps suggests the nonexistence of the greater problem; suggests, that is, that environmental contaminants not intentionally used in or on the commodity itself are not food additives. 
fines food additives as substances "the intended use of which" may reasonably be expected to result in the substances becoming a component of food, and explains that this definition includes "any substance intended for use in producing, manufacturing, packing, processing, preparing, treating, packaging, transporting, or holding food . . . ."115 The Ewig Brothers court felt that a substance in food is a "food additive" if that substance has been used at any point by any person for the purposes of food production. This interpretation would lead to the anomalous result that fish contaminated with pesticides used in the production of agricultural commodities would be contaminated as a matter of law under section $409^{116}$ but fish contaminated with industrial effluents would not. The more plausible interpretation is that the "intended use" to which the statute refers is that of the manufacturer or processor of the food commodity in which the substance is found. Section 409 regulates food additives by means of a premarketing mechanism designed to establish the safe levels at which a manufacturer or processor may use additives. The user must petition for a regulation permitting its use, and is responsible for bringing such use into conformity with the terms of the governing regulation. ${ }^{117}$ If the processor of the commodity in question does not use the foreign substance, the substance is not amenable to the regulatory scheme of section 409 , for the agency cannot formulate regulations prescribing the terms and conditions of the use of a substance that the processor does not use. The agency has ample authority, under sections 402 and 406, to remove from the market any food adulterated by contaminants that enter the food by accident or through the ecological pyramids. ${ }^{118}$

"1' 21 U.S.C. \$ 321 (s) (1970).

"I6 If a substance is a "food additive" it is deemed unsafe "with respect to any particular use or intended use" in the absence of a regulation prescribing the terms of its use. FDCA $\S$ 409(a), 21 U.S.C. $\$ 348$ (a) (1970).

117 Thus one commentator has argued:

It seems inconsistent with the legislative purpose to maintain that any substance is a food additive, regardless of whether its use in the distributive chain was reasonably foreseeable since in such cases there would be no possibility of pretesting to determine a safe amount. Thus, accidental additives, such as detergents used to clean the floors of the plant, which might conceivably but unexpectedly become components of the food, were exempted from the pretesting requirements since industry could have no way of either knowing or controlling the amounts which might eventually contaminate the food. 21 Vill. L. Rev. 140, 148-49 n.56 (1975). The note author emphasizes foreseeability, but the crucial issue seems to be control. Even if it can be reasonably foreseen that a product will be contaminated by DDT, for example, as a result of its ubiquity in the food pyramids, the contamination is nevertheless not a food additive, for it is not "used" on the product and therefore is not amenable to $\S 409$ pretesting.

is See text and note at note 16 supra. 
The "food additive" definition is perhaps worded broadly enough to encompass certain kinds of environmental contaminants. If a processor or packer purposely uses a contaminant in such a way as to permit the contaminant to enter the food commodity, the processor's use of the contaminant is amenable to section 409 regulation. For example, processors who use packaging paper contaminated with polychlorinated biphenyls (PCBs) should be subject to section 409 regulation. $\mathrm{PCBs}$, known carcinogens ${ }^{119}$ found in certain types of food packaging paper, can enter food by migrating from the surrounding paper. The presence of PCBs in certain types of paper is evidently due to environmental contamination. ${ }^{120}$ The use of packaging material containing PCBs is clearly an intended use of the paper in the distributive process that can reasonably be expected to result in the PCBs becoming a component of the food. PCBs in packaging paper therefore might be considered food additives so that the FDA could prohibit the use of such paper under conditions enabling $\mathrm{PCB}$ migration.

In general, however, foods containing environmentally pervasive carcinogens, or carcinogens produced through natural processes, such as fungus growth, ${ }^{121}$ are not subject to the anticancer proviso of section 409 (c)(3)(A). Such contaminated food must be regulated as food containing added poisonous substances under section $402(a)(1)^{122}$ or $402(a)(2)(A) .{ }^{123}$ Under these sections of the stat-

119 See Nagasaki, Tomii, Mega, Marugami \& Ito, Hepatocarcinogenicity of Polychlorinated Biphenyls in Mice, 63 GANN 805 (1972). See also Environmental Defense Fund Citizen Petition on PCB's (FDA, November 21, 1975). See generally Ueda, Toxicological Aspects I, The Toxicity of PCBs in PCB Poisoning ANd Pollution 32 (K. Higuchi ed. 1976).

${ }^{120} \mathrm{See} 39 \mathrm{Fed}$. Reg. 42743 (1974); In the Matter of Polychlorinated Biphenyls, No. FDC 82 (FDA 1975).

121 See text and notes at notes 129-34 infra.

12221 U.S.C. $\$ 342(a)(1)(1970)$.

12321 U.S.C. $\$ 342(a)(2)(A)(1970)$. Substances which are "added" but are not considered food additives are regulated under $\S \S 402$ and 406 of the Act. A few judicial decisions have attempted to determine whether a substance was "added." In United States v. 1,600,800 Pounds of White Corn, Civil No. T-4173 (D. Kan. Dec. 18, 1970), the court held that since aflatoxin is not a natural constituent of corn, it must be considered an added substance. The court recognized that aflatoxin is the byproduct of a mold that grows from spores not found on corn prior to harvesting. In United States v. 1232 Cases of American Beauty Brand Oysters, 43 F. Supp. 749 (W.D. Mo. 1942), the court held that shell fragments in cans of oysters were "not added" substances under $\S 402(a)(1)$, and that tolerances for shell fragments could therefore not be issued under $\S 406$. The court stated that the shell fragments were "not artificially added for the purpose of growth or to aid in the processing operations." Id. at 750. The FDA has asserted that the word "added" refers not only to substances purposely added, but to all substances not inherent in nature. See 39 Fed. Reg. 42743, 42744 (1974). That position received judicial approval in United States v. An Article of Food Consisting of Cartons of Swordfish, 395 F. Supp. 1184 (S.D.N.Y. 1975) (mercury in swordfish held an added substance). Although it may be difficult in some cases to determine if a substance 
ute, the FDA bears the burden of establishing the harmfulness of the food or of the ingredient, ${ }^{124}$ and tolerance levels can be established under section 406 for necessary or unavoidable carcinogenic substances. The FDA presently sets tolerances for such substances, but does not bear the burden of proving the harmfulness of food containing environmental carcinogens, since such substances are deemed unsafe under section 409 in the absence of a regulation specifying the permissible terms of their use. Thus the agency shifts the burden of proof to manufacturers by treating environmental carcinogens in food as food additives while avoiding the mandate of the anticancer proviso in section 409.

The manner of regulating the presence in food of environmentally ubiquitous carcinogens that has emerged is rather eccentric, but not unsatisfactory in policy. The FDA is unlikely to take the drastic action with respect to such carcinogens that Ewig Brothers seems to require-for essentially the same reason the agency has refused to apply the anticancer clause of section 409 to nitrites and selenium. ${ }^{125}$ Congress has never squarely addressed the problem of how to regulate carcinogenic food additives that are truly unavoidable or that are essential in the production of food. If the presence in food of substances such as DDT or selenium is to be systematically regulated, Congress, not the agency, should strike the fundamental balance of social costs and benefits. But until basic legislative decisions are made and standards erected, the FDA has no choice but to muddle through, backing and filling as events require.

Assuming that the Ewig Brothers decision and the FDA position will remain the law, at least for the near future, it is imperative that the criteria for determining unavoidability, as well as the standards for regulating unavoidable substances, comport with the general public health purposes of the Act. Acting under section 406, the FDA now permits the use of packaging paper containing $\mathrm{PCBs}$, on the theory that PCB migration is unavoidable. ${ }^{126}$ The agency, however, has admitted that PCB migration can be avoided by interposing a barrier between the packaging paper and the food. ${ }^{127}$ The con-

in food is "inherent in nature," see Note, Health Regulation of Naturally Hazardous Foods: The FDA Ban on Swordfish, 85 HARv. L. REv. 1025, 1030-32 (1972), the presence of pesticide residues in food is undeniably the result of man's use of the pesticide.

121 See note 16 supra.

123 Selenium and nitrites are clearly food additives. By a restrictive interpretation of the term "induce" in the anticancer clause, the FDA regulates selenium and nitrites under the safety clause. See text and notes at notes 39-55 supra.

12 21 C.F.R. $\$ 109.30$ (1977).

127 See 38 Fed. Reg. 18096, 18100 (1973). 
cept of unavoidability should not be thus stretched for the purpose of avoiding the mandate of the anticancer clause. ${ }^{128}$

Furthermore, the level of adulteration considered unavoidable should not necessarily be dictated by the standards the food industry has set for itself. The FDA, in its proposed regulation of aflatoxin, a contaminant of peanuts, chose a 15 p.p.b. tolerance level ${ }^{128}$ primarily, it appears, because that was thought to be "a level at which manufacturers have the capability to monitor their products during processing and to ensure that the finished product complies with the tolerance"130 - even though eleven of the twelve major producers of peanut prooucts could meet a 10 p.p.b. tolerance in 90 percent of their products. ${ }^{131}$ Aflatoxin is a potent carcinogen ${ }^{132}$ produced by a type of mold that grows on peanuts. ${ }^{133}$ By immediately drying and properly storing the harvested peanuts manufacturers could substantially reduce the production of aflatoxin. ${ }^{134}$ The FDA elevated industry convenience and security over public health considerations by refusing to adopt an industry-leading standard. Judge Learned Hand's classic statement concerning the deference due industry usage under the law of torts seems apposite in this context:

[1]n most cases reasonable prudence is in fact common prudence; but strictly it is never its measure; a whole calling may have unduly lagged in the adoption of new and available devices. It may never set its own test, however persuasive be its

12x Insofar as practicable, the agency should preserve the integrity of the Food Additives Amendment as an independent regulatory scheme prescribing more stringent safety standards than those contained in the general "poisonous and deleterious" sections of the Act. Cf. Continental Chemiste Corp. v. Ruckelshaus, 461 F.2d 331 (7th Cir. 1972) (dictum that subsequent to the passage of the Food Additives Amendment, if a product constitutes a "food additive" it is excluded from the "poisonous" or "deleterious" category).

12039 Fed. Reg. 42748,42750 (1974). The FDA proposes to establish a $\$ 406$ tolerance on the ground that aflatoxin contamination is unavoidable.

${ }^{130}$ Id.

131 Id.

132 Aflatoxin induces tumors in rats when fed 1 p.p.b. of their daily diet. See Wogan, et al., Carcinogenic Effects of Low Dietary Levels of Aflatoxin $B^{1}$ in Rats, 12 Food Cos. ToxicoLOGY 681 (1974). In other experiments one hundred per cent of the rats fed aflatoxin as 15 p.p.b. of their daily diet developed tumors. See Wogan \& Newbern, Dose-Response Characteristics of Aflatoxin $B^{1}$ Carcinogenesis in the Rat, 27 CANCER RESEARCH 2370 (1967). For further discussion of the carcinogenicity of aflatoxin, see Health Research Group, Comment on Fed. Reg. Proposals (Dec. 6, 1974) (FDA, 1974).

izs See Nat'l Academy of Sciences, Toxicants Occurring Naturally in Food 26 (1966). It was first isolated when 100,000 turkeys died in England from "Turkey X" disease. R. Suss., V. KIWZEL, J. SCRIBNER, CANCER 7 (1973).

${ }^{134}$ See Ashworth, Schroeder \& Langley, Aflatoxins: Environmental Factors Governing Occurrence in Spanish Peanuts, 148 ScIENCE 1228 (1965). 
usages .... [T]here are precautions so imperative that even their universal disregard will not excuse their omission. ${ }^{135}$

\section{B. Food Additives: The Statutory Exceptions}

The two statutory exceptions from the food additive definition raise special problems. Congress specifically excepted from the anticancer clause substances that experts "generally recognize as safe" (GRAS) ${ }^{138}$ The purpose of the GRAS exception was to exempt common additives such as salt, sugar, and vinegar from the pretesting requirement of section $409 .{ }^{137}$ Also excepted were substances granted a sanction prior to the enactment of the Food Additives Amendment. ${ }^{138}$ Prior sanctions were FDA informal opinions acknowledging the safety of chemicals intended for use in food..$^{139}$

Since GRAS additives and additives granted a prior sanction are regulated under the "poisonous and deleterious" sections of the Act, these statutory exceptions might appear to create substantial impediments to the effective implementation of the anticancer clause. Both GRAS and prior sanction additives, however, can be withdrawn. The GRAS exception requires a general consensus among scientists that the exempted substance is safe. Any suspicion

${ }^{135}$ The T.J. Hooper, 60 F.2d 737, 740 (2d Cir.), cert. denied, 287 U.S. 662 (1932) (cited in Consumers Union, Poisonous or Deleterious Substances in Food; Proposed Tolerance for Aflatoxins in Shelled Peanuts and Peanut Products and Lead in Evaporated Milk and Proposed Action Level for Mercury in Fish and Shellfish (Comments on Proposed Rulemaking, March 6, 1975)).

136 FDCA § 201(s), 21 U.S.C. \& 321(s) (1970).

137 Food Drug Cos. L. Rep. (CCH) i 55,051.40 (HEW Release 135, Sept. 10, 1958). There were approximately 180 GRAS substances at the time of the Amendment's enactment. Food Drug Cos. L. REP. (CCH) ๆ 55,051.44 (HEW Release L. 79, Nov. 20, 1959). The number has grown to approximately 675. Spiher, Food Ingredient Review, FDA Consumer, June, 1974, at 23. There is not a single GRAS list, although the FDA has published a partial list. See 21 C.F.R. $\$ 121.101$ (1975). Substances not included on this list are not automatically classified as food additives. Manufacturers may form their own conclusion whether a substance is GRAS; if they are in error, the food containing such additives will be considered adulterated. See 14 Food Drug Cos. L.J. 9 (1959). Several groups, including the flavor, the chewing gum, and the brewing industries, have published lists. The FDA has presumed some substances to be GRAS without publication, and has issued "no objection letters," usually unpublished, on other substances. See generally The Use of Substances "Generally Recognized as Safe" (July 20, 1973) (unpublished FDA release).

13s FDCA \& 201(s)(4); 21 U.S.C. \& 321(s)(4) (1970).

139 The number of prior sanction letters has been estimated to be between one and ten thousand. See Turner, supra note 5, at 312. Many of the sanctions that have been granted cannot be ascertained because of the destruction of old records and the retirement of personnel from the FDA. 37 Fed. Reg. 16407 (1972). The FDA now attempts to publish all prior sanctions as they become known, see 21 C.F.R. $\$ 121,2000$ (1976), and to replace old prior sanctions with "qualified and current opinions." See 21 C.F.R. \$ 121.11 (1976). For a discussion of the effect of these regulations, see Food CHEmical News, April 13, 1970, at 39. 
that an additive may induce cancer should be sufficient to prevent it from being "generally recognized as safe." 140 Revocation of a prior sanction is more difficult. Such sanctions can be withdrawn only under the safety standards of sections 402 and 406 . Those standards place on the FDA the burden of showing that the substance may be injurious to health; thus, withdrawal could not be effected on the basis of inconclusive data. ${ }^{141} \mathrm{~A}$ clear demonstration that a substance is carcinogenic, however, should suffice for revocation of a prior sanction. ${ }^{142}$

\section{Animal Drugs: The DES Amendment}

The DES Amendment ${ }^{143}$ authorizes the FDA to approve the use of any carcinogenic animal drug if, after testing of the drug by "methods approved by the Secretary," no residue of the drug can be found in any edible portion of the animal. The clause was enacted in 1962 to permit the continued use of diethylstilbestrol (DES). ${ }^{144}$ At that time, the carcinogenicity of DES was well established, ${ }^{145}$ but there was no evidence that cattle to which the drug had

${ }^{140}$ For example, saccharin was withdrawn from the GRAS list in 1971 on the basis of evidence suggestive of its carcinogenicity. 21 C.F.R. $\$ 121.101$ (1970). The regulation permitted continued use within limitations while further tests were being conducted. 36 Fed. Reg. 12109 (1971).

is See T. Christopher \& W. GoOdRTCh, supra note 16 , at 531.

112 The prior sanction status of safrole was revoked after evidence clearly demonstrated its carcinogenicity. 25 Fed. Reg. 12412 (1960). See generally Lehman, Report on Safrole, 25 Q. BuLl. Ass'N Food \& DRUG OFFICIALS 194 (1961).

${ }^{143}$ FDCA $\S 512(d)(1)(H), 21$ U.S.C. $\S 360 \mathrm{~b}(\mathrm{~d})(1)(\mathrm{H})(1970)$.

i4 DES is a synthetic estrogen widely used either as a food additive or as implanted pellets to increase the growth rate of ruminants. See generally Burroughs, Culbertson, Chang, Hale \& Homeyer, The Influence of Oral Administration of Diethylstilbestrol to Beef Cattle, 14 J. ANIMAL Sci. 1015 (1955).

The DES Amendment, although drafted with specific reference to diethylstilbestrol, applies to all animal drugs. Issues similar to those presented in the DES cases are arising with respect to a group of drugs known as nitrofurans. There are four nitrofurans used in foodproducing animals: nitrofurazone, nihydrazone, furazolidone, and furaltadone. Like DES, nitrofurans are carcinogenic. Office of the Comptroller General, Use of Cancer-Causing Drugs in Food-Producing Animals May Pose Public Health Hazard: The Case of Nitrofurans (February 25, 1976); 41 Fed. Reg. 19906 (1976); 41 Fed. Reg. 34884 (1976); In the Matter of Furazolidone, No. 76N-0172 (FDA, August, 1976).

${ }^{115}$ See, e.g., Gusberg, Precursors of Corpus Carcinoma, Estrogens and Adenomatous Hyperplasia, 54 Am. J. Obstetrics \& Gynocology, 905 (1947); Shimkin \& Grady, Toxic and Carcinogenic Effects of Stilbestrol in Strain C3H Male Mice, 2 J. NAT'L CANCER INST. 55 (1941). In 1971, Herbst reported seven cases of vaginal adenocarcinoma in daughters of women who had taken DES during pregnancy for threatened abortion. Herbst, Ulfelder \& Puskanzer, Adenocarcinoma of Maternal Stilbestrol Treatment with Tumor Appearance in Young Women, 284 NEw Eng. J. MED. 878 (1971). About 80 additional cases have been reported. Hernonin, Diethylstilbestrol in Pregnancy: Frequency of Exposure and Usage Patterns, 31 CANCER 573 (1973). 
been administered retained any residue of DES after slaughter.

Since the enactment of the DES Amendment, the analytical methods for detecting residues have improved dramatically. ${ }^{148}$ After the Department of Agriculture in 1972 detected what appeared to be DES residues in beef, the FDA attempted to remove DES from the market. ${ }^{147}$ In Hess \& Clark, Division of Rhodia, Inc. v. FDA, ${ }^{148}$ the D.C. Circuit vacated the withdrawal on the grounds that the agency had not provided the manufacturers an adequate opportunity for a hearing, and remanded the case to the FDA. Following remand, the FDA announced a hearing on its proposal to withdraw the prior approval of DES. ${ }^{148}$

The main controversy in that hearing will center on whether the substances found in DES-treated animals are "residues" within the meaning of the statute. Drugs may be chemically altered after ingestion and the substance detected in the tissues of slaughtered animals may be something quite different from the administered drug. ${ }^{150}$ The manufacturers of DES argue that "a residue is the remainder of the original substance and the term 'residue' should not be used to describe new compounds formed from the original substance." 151 They claim that the residue contained in the animal tissues is a metabolite of DES, DES-monoglucuranide, and assert that the metabolite, unlike free DES, is not carcinogenic. ${ }^{152}$

The statute and legislative history leave unclear whether Congress intended metabolites to be included within the term "residues," or whether metabolites must be independently evaluated for carcinogenicity. As a practical matter, metabolites are often present in trace amounts and can be difficult to identify, isolate,

146 In 1962 the detection of a few parts per million (the mass ratio of the constituent to its parent specimen) was considered rare. Today, the detection of a few parts per trillion can be achieved in some instances. For example, the bioassay method used to detect DES in the 1950 's reached a sensitivity of 50 p.p.b. In the 1960 's, the use of gas chromatography permitted detection of 5 p.p.b. Recently, radioimmunoassay has been able to detect 0.5 p.p.b. See 1975 Appropriations Hearings, supra note 83, at 7.

117 For the chronology of events that led to the attempted withdrawal of DES, see Byerley, So Are They All-All Honorable Men: A Review of the DES Revocation Cases to Date, 29 Food Drug Cos. L.J. 460 (1974).

it8 495 F.2d 975 (D.C. Cir. 1974).

31" 41 Fed. Reg. 52105 (1976).

150 See generally Morrison \& Munro, Appraisal of the Significance to Man of Drug Residues in Edible Animal Products, in Nat'z Academy of Sciences, The Use of Drugs in Andmal FEeDs 255-69 (1969).

131 Affidavit of Bernard Kliman, M.D., at 2, In the Matter of Diethylstilbestrol, No. 76N0002 (FDA, Feb. 9, 1976).

152 Written Appearance and Request for Hearing of Vineland Laboratories, Inc., at 8, In the Matter of Diethylstilbestrol, No. 76N-0002 (FDA, Feb. 11, 1976). 
and test. ${ }^{153}$ If scientific evidence establishes a significant possibility that metabolites have the carcinogenic properties of their parent chemicals and that individual testing is not practical, the FDA would be justified in establishing a presumption that such metabolites fall within the anticancer clause. The DES Amendment granted an exception to the anticancer clause for known carcinogens only on the assumption that the use of such carcinogens would not result in human ingestion of carcinogenic chemicals; if there is evidence that the assumption is incorrect, the DES exception should not apply. On the other hand, it would not be inconsistent with the purpose of the DES Amendment to permit the use of a drug that leaves a metabolite in the slaughtered animal so long as there is convincing evidence that the metabolite is not itself carcinogenic.

A second issue crucial to the proper administration of the DES Amendment concerns testing methods. The statute prescribes that the methods of detecting residues shall be those "approved by the Secretary." It has been argued, therefore, that the law does not require the use of the most sensitive method of analysis. ${ }^{154}$ At the time of enactment of the Amendment, Congress recognized that the ability to measure a "zero" quantity of residue was limited by the sensitivity of the method employed. ${ }^{155}$ However, there is no indication that Congress purposely sanctioned the presence of minute quantities of residues in human food. Congress had no intention of weakening the anticancer clauses; indeed, the legislators were expressly assured that the DES Amendment would not compromise "the consumer protection now afforded by [the anticancer] provision." ${ }^{156}$ Assurance was made that the "basic principle of the anticancer provision"- the no-threshold hypothesis-would "remain unimpaired." 157 The legislative history of the DES Amendment thus suggests that use of the most sensitive method of analysis should be required under the Amendment.

The FDA has expressed dismay at the prospect of requiring the

${ }_{153}$ See Kolbye \& Perez, supra note 58, at 3.

154 See, e.g., Cong. REC. H5945 (daily ed. June 16, 1976) (remarks of Rep. Whitten): "Testimony before the committee has highlighted the fact that the Secretary of HEW is charged with the responsibility of approving a method for the measurement of residues. The law does not require the present practice of using the most sensitive method available."

1ss See 108 Cong. REc. 21077 (1962).

ist The quotation in the text is from a section by section analysis of $H . R$ s 11581 forwarded to the House Committee on Interstate and Foreign Commerce in 1962 by the HEW Secretary, cited in Regulation of Diethylstilbestrol (DES): Hearings before the Intergovernmental Relations Subcomm. of the House Comm. on Government Operations, 92d Cong., 2d Sess. 381 (1972).

${ }^{157}$ Id. 
most sensitive method of detection. ${ }^{158}$ A policy of continually adopting new methods of detection as such methods are developed might frustrate the hope, expressed in 1962 by the Secretary of HEW, that statutory authority to prescribe detection methods could be used to ensure that "industry, laboratory technicians, and enforcement officials [will] have a common understanding with the Food and Drug Administration as to the methods of assay that will be recognized by us on which we intend to rely in resolving the question of residue."159 But the Secretary did recognize that only reasonable certainty could be achieved because "such regulations may from time to time be changed as new scientific developments demonstrate a need for change." 160

The FDA has recently promulgated regulations adopting sensitivity of the method principles (SOM) under its authority to prescribe the methods to be used in detecting residues. ${ }^{11}$ The SOM principles do not specify that a certain analytic method be used in testing for residues, but instead establish for each drug a level of residue exposure that the agency considers "safe" and require that the assay method chosen be capable of measuring to the defined level. ${ }^{162}$ The theoretical calculation by which the safety level is de-

${ }^{158}$ FDA Commissioner Schmidt has recently stated that mandatory use of the most sensitive method "means that we will be chasing a receding zero and some idiot in some lab will come up with something sensitive to parts quintillion, and on our policy it says we will adopt it." National Advisory Food and Drug Committee, FDA, Transcript of Proceedings of June 29-30, 1976, at 2-56 (remarks of Alexander Schmidt, FDA Commissioner).

139 1975 Appropriations Hearings, supra note 83, at 204 (report by Secretary of HEW to the House Comm. on Interstate and Foreign Commerce, reprinted from H.R. REP. No. 2464, 87th Cong., 2d Sess. (1960)).

160 Id. at 204.

161 38 Fed. Reg. 19226 (1973); 42 Fed. Reg. 10412 (1977) (codified at 21 C.F.R. $\$ \S 500.80$ .98 (1977)). FDA has indicated its intention to apply the SOM rules to nitrofurans. See 41 Fed. Reg. 19906 (1976); 41 Fed. Reg. 34884 (1976). For a general discussion of these proposed regulations, see Robens, Criteria for Acceptable Methods to Detect Drug Residues, 29 Food DRug Cos. L.J. 39 (1974).

162 As outlined in the Food \& Drug LETTER, September 3, 1976, at 3, the following steps would be required of a manufacturer who wishes to market an animal drug that is a suspected carcinogen:

[1] Assess total residues in edible products and their depletion times, in order to ascertain probable human consumption.

[2] Determine appropriate testing in laboratory animals to estimate the cumulative effects of human exposure to the residues.

[3] Use dose-response data in test animals to extrapolate to a level of residue exposure that FDA considers insignificant and posing essentially no risk of cancer.

[4] Determine the animal tissue from which the residues require the longest time to deplete to safe levels, and the compound the assay must measure to assure that no unsafe residues occur.

[5] Develop a practicable method of analysis to assure that total residues in the daily diet of humans do not exceed the safe level. 
termined is based on an estimate of the quantity of the drug that would yield a one in one million chance of producing cancer. ${ }^{163}$

This statistical extrapolation method is fraught with difficulties. Adoption of a theoretical estimate of safety for a disease whose mechanisms of induction are so little understood must be viewed with skepticism. No theoretical estimate can take into account either the variability of human susceptibility to carcinogens or the individual hormonal and immunological mechanisms that affect the growth of tumors once they have been initiated. ${ }^{164}$ Moreover, the assumption that science can estimate the risk that a chemical will cause cancer is fundamentally at odds with the no-threshold hypothesis. The difficulties associated with any statistical extrapolation method reinforce the conclusion that it is better and more consistent with the policy of the Delaney clause to require the most sensitive method of detection that is both reliable and reproducible.

\section{Conclusion}

This comment has examined several problems that have arisen in the application of the anticancer clauses. The problems are difficult, but not insurmountable. Full implementation of the anticancer policy requires a substantial effort from the FDA, particularly in formulating scientific standards to guide legal judgments. The strictly legal problems-problems of statutory interpretation-may require legislative attention, particularly in the area of regulating the marketing of food contaminated by environmental carcinogens such as DDT. The FDA, perhaps with some justification, has strayed from the strict anticancer policy of the Act in certain respects. Legislative clarification would provide the agency with much needed guidance in its task of protecting the public health.

David A. Kessler

[6] Demonstrate that the product label can prescribe practical conditions of use to assure there will be no unsafe residues.

16542 Fed. Reg. 10412, 10431 (1977) (codified at 21 C.F.R. $\S 500.87$ (1977)). The method of extrapolation is based upon Mantel \& Bryan, "Safety" Testing of Carcinogenic Agents, 27 J. NAT'L CANCER INST. 455 (1961); Mantel, et al., An Improved Mantel-Bryan Procedure for "Safety" Testing of Carcinogens, 35 CANCER RESEARCH 865 (1975).

164 See Health Research Group, Comments on the Proposed FDA Regulation "Compounds Used in Food Producing Animals" (Sept. 17, 1973). 